\section{E-LOGOS}

ELECTRONIC JOURNAL FOR PHILOSOPHY ISSN 1211-0442

$6 / 2012$

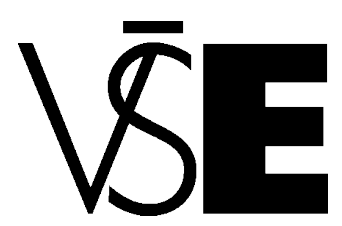

University of Economics

Prague

\title{
Je biologická evolúcia slabo, stredne alebo silne usmerneným procesom?
}

Robert Burgan

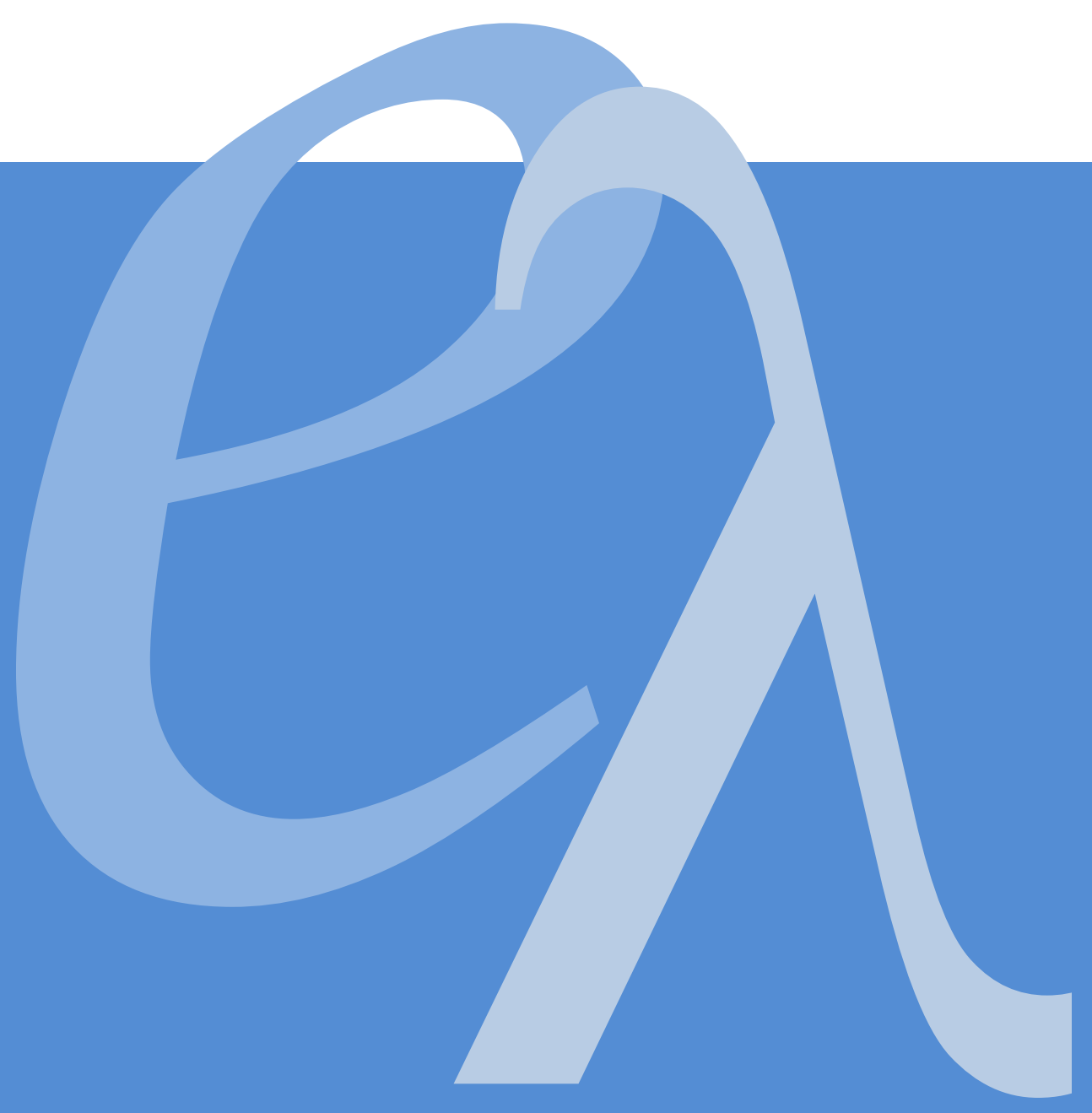




\begin{abstract}
The following Paper attempts to discuss whether the biological evolution is an autonomous and peculiar process sui generis, i.e. of its respective type with own specific biological laws with clearly separable and explicit line from less progressive organisms up to ever more progressive ones, or whether it is only secondary strongly stochastic or even totaly contingent process that is not determined by any specific biological laws or "rules" having no clearly separable and explicit line from less progressive organisms up to ever more progressive ones, and in the event it would be repeated under significantly unchanged reproduction conditions then it would proceed in a completely different way with completely different continuous results. Based upon numerous national and foreign evolution-biological literature we came to a conclusion that the supporters of the first standpoint seem to be closer to truth as they consider the biological evolution to be a medium directed process with its own structural elements and dynamic laws and ever progressive "units" however the process without existence of conscious direction is not so strongly directed as it is in case of subsequent social developmental process having its own elements and laws or "rules".
\end{abstract}

Keywords: weakly, medium and strongly directed processes; biological and socialcultural evolution; dynamic and stochastic laws; immanent laws of self-developing inanimate, animate and social systems; forms of movement of matter and laws of their organic reproduction. 


\begin{abstract}
Abstrakt
V nasledujúcom článku diskutujeme o tom, či je biologická evolúcia autonómnym a svojbytným procesom sui generis, t. j. svojho druhu, s vlastnými špecifickými biologickými zákonmi, s jednoznačne vyčlenitel'nou a zretel'nou líniou od menej progresívnych organizmov $\mathrm{k}$ čoraz viac progresívnejším, alebo len sekundárnym, silne stochastickým či dokonca úplne kontingentným procesom, ktorý nie je riadený žiadnymi špecificky biologickými zákonmi či "pravidlami“, nemá žiadnu jednoznačne vyčlenitel'nú a zretel'nú líniu od menej progresívnych organizmov k čoraz viac progresívnejším a ak by sa mal zopakovat' pri výrazne nezmenených reprodukčných podmienkach, tak by určite prebiehal úplne inak, s úplne inými priebežnými výsledkami. Vychádzajúc z pomerne početnej vzorky domácej, ako aj zahraničnej evolučno-biologickej literatúry napokon konštatujeme, že bližšie k pravde sa zdajú byt' zástancovia prvého stanoviska, považujúci biologickú evolúciu za stredne usmernený proces s vlastnými štruktúrnymi prvkami, dynamickými zákonmi a čoraz progresívnejšími ,jednotkami“, ktorý však pri neexistencii vedomého usmerňovania nie je až tak silne usmerňovaný ako po ňom nasledujúci sociálny vývojový proces s jemu vlastnými prvkami, zákonmi či „pravidlami“.
\end{abstract}

Klíčová slova: slabo, stredne a silne usmernené procesy; biologická a sociálnokultúrna evolúcia; dynamické, stochastické, empirické a apriórne zákony; fyzikálne a biologické explanácie; formy pohybu hmoty a zákony ich organickej reprodukcie. 


\section{Úvod}

$\mathrm{Na}$ začiatku 21. storočia sa na prvý pohl'ad zdá byt' situácia tzv. environmentálnych hnutí či politických strán úplne beznádejná. Nielenže sa rozdrobili do viacerých konkurenčných či len vel'mi slabo prepojených a koordinovaných záujmových zoskupení s neraz vel'mi nejasným až temným sponzorským pozadím, ale $\mathrm{v}$ rámci celospoločenského diskurzu sú čoraz viac a čoraz agresívnejšie vytesňované na okraj všemožnými zástancami tzv. vol'ného trhu a centrálne neriadenej globálnej ekonomiky (typu Václava Klausa či Bjørna Lomborga, 2006). Ako ale ukazujeme v našom článku, za všetky tieto porážky a zlyhania si v podstate a predovšetkým môžu environmentalisti (a nimi zakladané „zelené" politické hnutia či strany) sami, pretože svoje programy postavili na filozofiách alebo ideológiách, ktoré ich dopredu paralyzovali či „znefunkčnili“ pri akejkolvvek trochu dôslednejšej snahe o navodenie želanej celoplanetárnej „probiotickej“ zmeny. Nemáme pritom na mysli len zistenia predložené B. Binkom (2008), poukazujúce na ich fatálnu závislost' od iracionálnych východných „učení“ či antihumánnej hlbinnej ekológie (Devall-Sessions, 1997), ale aj a predovšetkým ich príklon k biocentrickým koncepciám typu Gouldovej (1988) či Markošovej (2003) „panbiologickej“ evolučnej teórie.

\section{Gould alebo Stanko, kritický racionalizmus alebo dialektický materializmus?}

Stephen Jay Gould (1941-2002), ako každá silná vedecká osobnost', v mnohom pozitívne, ale v mnohom aj vel'mi negatívne ovplyvnil dejiny vedeckej disciplíny, t. j. evolučnej biológie, v rámci ktorej dlhé roky pôsobil, vychádzajúc pritom, čo je skutočnost', na ktorú filozofi biológie na naše vel'ké prekvapenie dost' zriedka upozorňujú, najmä z Popperovho kritického racionalizmu (1994a, 1994b, 1997), podl'a ktorého tzv. tvrdé alebo nomologické zákony môžu platit' len v rámci fyziky a chémie, kde a kedy platia univerzálne, t. j. vždy a všade, pričom je možné predložit' kauzálne vysvetlenie, zatial čo v rámci tzv. mäkkých vied, ako sú napríklad biológia alebo história, takéto univerzálne platné zákony neexistujú a namiesto jednoznačného kauzálneho vysvetlenia udalostí a fenoménov musí príst' len ich vol'né „prerozprávanie“ či dodatočné „zrekonštruovanie“ pomocou tzv. abduktívnej metódy (dodatočne a aposteriórne nachádzajúcej hlavné súvislosti). V úplnom súlade stýmito Popperovými ideami potom Gould sformuloval aj svoje najdôležitejšie idey vzt'ahujúce sa k biologickej evolúcii, tvrdiac, že žiadny pokrok v nej neexistuje (in Davies, 2001, s. 278-279) a samotná biologická evolúcia práve preto, že nie je usmerňovaná žiadnymi zákonmi, musí byt́ unikátna a neopakovatelná. ${ }^{1}$

\footnotetext{
${ }^{1}$ Ked’že, ako usudzuje Gould vo svojej slávnej knihe o Burgesskej lavičke (1989; in Turner, 2011, s. 66-69) na základe modelovania možného priebehu speciácie (t. j. vzniku nových druhov v rámci evolučného procesu), realizovaného tzv. MBL skupinou, už pri malých zmenách počiatočných podmienok biologického evolučného
} 
Gouldove východiskové idey, ako to už býva v malých a efemérnych kultúrach, ktoré nemajú dost' prostriedkov ani kapacít na to, aby mohli plnohodnotne prevziat' poznatkové dedičstvo väčších a t'ažiskových kultúr (ako je anglosaská, nemecká, ruská či francúzska), boli takmer bezvýhradne prevzaté tak českou, ako aj slovenskou biologickou obcou, pričom v rámci pre nás Slovákov i Čechov typického mantinelizmu (t. j. oportunistického prebiehania od jedného názorového extrému k druhému) boli okamžite odsunuté do zabudnutia predtým rovnako bezvýhradne akceptované idey sovietskych evolučných biológov (ako A. Jablokova a A. Jusufova, 1985 a i.) o strednej usmernenosti biologického evolučného procesu. Zvlášt' nápadným príkladom takéhoto značne jednostranného prístupu je spoločná práca J. Zrzavého, D. Storcha a S. Mihulku (2004), v ktorej sa síce vel'mi prístupným a čitatel'sky prít́ažlivým spôsobom demaskujú mnohé mylné tvrdenia o biologickej evolúcii ako takej, vrátane tvrdení o neexistencii tzv. prechodných článkov medzi jednotlivými druhmi, či mimoriadne vysokej nepravdepodobnosti vzniku zložitých orgánov $^{2}$, ale zároveň sa Gouldove vyššie uvedené idey nekriticky preberajú bez akejkol'vek hlbšej, sústavnejšej alebo dôkladnejšej autorskej reflexie.

Hned' na 24. až 25. strane svojej knihy tak Zrzavý et al. (d'alej aj ZSM) konštatujú, že vo fylogenéze živočíchov a rastlín si rovnako ako v histórii vel'ké udalosti (akou bol napríklad pád rímskej ríše) "len dodatočne vymýšlame“, že fylogenéza pozostáva len „z unikátnych udalostí, ku ktorým došlo iba raz", a tak sa na rozdiel od ustavične sa opakujúcej ontogenézy vôbec nemôže zopakovat'. To isté platí aj v historiografii (ako čisto popisnej vede), v ktorej takisto nemôžeme vysvetlit' napríklad napoleonské vojny len Napoleonovou psychikou, či sociálnou alebo ekonomickou situáciou vtedajšieho Francúzska, a tak pri neúplnosti týchto čiastkových (ale nerovnako závažných či pravdepodobných - R. B.) vysvetlení vraj urobíme najlepšie (tamže, s. 26), ked' sa opät' vrátime k starému predvedeckému dejepisu vojenských výprav, bitiek, svadieb či zrád, čiže k analógii „toho, čomu v evolučnej biológii hovoríme fylogenéza“, čo je však už tvrdenie, ktoré musí podozrivo zniet́ aj človeku, ktorý naposledy počul o biológii na základnej škole. V tom istom duchu potom ZSM tvrdia (tamže, s. 32; podč. R. B.), že selekcia vôbec „nie je nejaká zvláštna sila dozerajúca na organizmy, ale opis reprodukčnej dynamiky, ktorá vedie $\mathrm{k}$ tomu, že len niektoré alely v populácii pretrvajü“.

procesu sa budú jeho následné výsledky čoraz viac odlišovat' od tých, ktoré sme doteraz zaregistrovali, a tak nám nič nebráni konštatovat', že tento proces je tak principiálne nepredvídatel'ný, ako aj kauzálne nevysvetlitel'ný.

${ }^{2}$ Kedy komorové oko vzniká nezávisle u stavovcov, hlavonožcov, ba aj u niektorých medúz (tamže, s. 119, 158).

3 Ponechávajúc pritom čitatel'a v nevedomosti o tom, že okrem prirodzeného výberu existujú aj iné formy výberu, pri ktorých dochádza k triedeniu systémov podl’a ich vlastností - ako je napríklad samoorganizácia alebo triedenie systémov z hl'adiska ich stability, kedy takisto dochádza k vzniku komplexných štruktúr, ale už nielen v živých, ale aj v neživých systémoch, ako upozorňuje vo svojej knihe J. Flegr (2005, s. 37-42); ani nehovoriac o tom, že z ontologického hl'adiska sa zdá byt' celkom legitímne hovorit' o prirodzenom výbere nielen ako o čisto epistemickom prostriedku (čiže opise nejakého diania), ale aj ako o reálnej interakcii medzi živými systémami, počas ktorej zdatnejšie prežívajú a menej zdatné vymierajú, či o výsledku tejto interakcie. 
K našej problematike sa ZSM opät' vyjadrujú na 57. strane, ked' pod silným vplyvom Alice v krajine zázrakov (1984, s. 132) a tamojšej Čiernej královny konštatujú, a to vyslovene demagogicky, že (biologická) evolúcia nemôže byt' skutočne progresívna ani (plne) adaptívna, pretože ak by bola, tak by pravdepodobnost' bezprostredného vymretia organizmov postupne klesala, ked'že jednotlivé biologické druhy by sa postupne čoraz lepšie a viac prispôsobovali svojmu prostrediu, čo je ale podl'a nich nezmyselný predpoklad, pretože tieto druhy sa počas evolúcie nemajú ani lepšie, ani horšie, v dôsledku toho, že sa musia adaptovat' na okamžitý stav svojho životného prostredia, ktoré sa neustále mení (alebo rýchlo "beži“", ako v uvedenej rozprávke, pretože nie je tvorené len abiotickými podmienkami, ale aj d'alšími meniacimi sa druhmi - R. B.), a tak sa zo svojej interakcie s ním ani nedokážu "poučit"; čo znie na prvý pohl'ad celkom vierohodne, ale len dovtedy, kým si neuvedomíme, že počas evolúcie vzrastá nezávislost' živých systémov od ich abiotického prostredia, prejavujúca sa nielen ich zvýšenou pohyblivost'ou (čoho krásnym príkladom sú najmä st́ahovavé vtáky) ${ }^{4}$, ale aj teplokrvnost'ou, zatial' čo abiotické prostredie si svoje hlavné "probiotické" parametre dlhodobo zachováva.

Silný „odér“ antropomorfizmu (alebo antropocentrizmu), t. j. zámerného podsúvania l'udskej intencionality živej prírode, môžeme už zacítit' na 65. strane, kde Zrzavý et al. účelovo tvrdia, že l'udská spoločnost' je natol’ko zložitou siet'ou „vzt’ahov, že je v podstate nemožné vykalkulovat' si dlhodobo úspešnú stratégiu, a neostáva teda nič iného ako si len tak neuvedomelo žit'", na základe čoho by sme si aj samotnú evolúciu (tamže, s. 68; podč. R. B.) mali predstavovat' ako "nikdy sa nekončiacu hru“, v ktorej vôbec nejde o to, aby sme dosiahli nejaký ciel', ale len o to, aby sme v nej zostali; zatial' čo na 93. strane naopak prechádzajú do úplne nekritického biocentrizmu (t. j. začleňovania výsostne l'udských, sociálno-kultúrnych vlastností do biologického parametrického inventára), konštatujúc na základe fylogenetických (t. j. čisto biologických) výskumov, že väčšina l'udských vlastností nie je charakteristická pre l'udí, ale pre šimpanzov a l'udí, pričom u nás l'udí sú tieto spoločné vlastnosti len extrémne vyhrotené alebo "zdôraznené", v dôsledku čoho by sme vraj nemali považovat' za príčinu našej hominizácie bipédiu, lov, myslenie, symbolickú kultúru, druhú signálnu sústavu, ba ani používanie nástrojov, pretože toto všetko v jednoduchšej podobe nachádzame aj u šimpanzov.

Na 214. strane už vstupuje do hry pravdepodobnost', ked' ZSM znova zdôrazňujú, že „fylogenéza organizmov je jeden unikátny historický príbeh, pozostávajúci z udalostí, ktoré sa stali len raz, a preto ich nemožno hodnotit' pravdepodobnostne“", a to aj napriek tomu, že pri vyššie spomenutom posudzovaní pravdepodobnosti vzniku zložitých orgánov sami nielen uviedli, že vel'mi zložité komorové oko vzniklo počas fylogenézy nezávisle hned' trikrát, ale aj podotkli, že pri počítačovom

\footnotetext{
${ }^{4}$ Ako konštatuje B. Poršnev vo svojej epochálnej a u nás stále nedocenenej knihe (1979), alebo B. Rosslenbroich vo svojej nemenej pozoruhodnej štúdii (2009), ktorej závermi sa budeme zaoberat’ v druhej časti nášho článku.
} 
modelovaní vzniku komorového oka sa zistilo, že pri malých zvieratách, u ktorých je jeho vznik najpravdepodobnejší, môže toto oko vzniknút' už počas 400000 generácií, čiže zhruba za 500000 rokov, čo je d'alší argumentačný "prešlap", na existencii ktorého nemení nič ani ich následné vcelku správne konštatovanie, že „uvažovat’ o pravdepodobnostiach má význam len tam, kde máme k dispozícii súbor porovnatel'ných udalostí, ktoré niekdy dopadnú tak a inokedy onak“. O to nepresvedčivejšie potom pôsobí ich tvrdenie na 215. strane, že "fylogenéza je sekvencia historických udalostí, ktoré nemusia smerovat' (a zvyčajne ani nesmerujú) k dôsledkom, ktoré by sme označili za ,logické'“, najmä ak sa v tomto prípade účelovo prenáša do empirickej biologickej vedy čisto logické dôvodenie.

A už úplne mimo štandardnej vedeckej a filozofickej argumentácie sa ZSM ocitajú, ked' sa v rozpore s bádatel'skou tradíciou i životnou skúsenost'ou väčšiny $z$ nás snažia presvedčit' čitatel'a (tamže, s. 215), že „zo spätného pohl'adu sa nám dejiny vždy javia ako postupnost' divokých náhod, udalostí s minimálnou pravdepodobnost'ou, že sa vôbec stanú“, v rámci ktorej tak nejaké všeobecné sociologické a ekonomické trendy „môžeme vidiet' iba z vel'kého a dost' násilného nadhl'adu“, dodávajúc dokonca (tamže, s. 215-216), že ak aj v dejinách (či v samotnej fylogenéze - R. B.) nejaké zákonitosti predsa len sú, tak im asi žiadna jednotlivá udalost' „úplne nezodpovedá, pretože každá zahŕňa významný podiel historickej náhodnosti“, a znovu tak potvrdzujúc, že im chýbajú elementárne poznatky tak o vzájomnom vztáahu tzv. dynamických a pravdepodobnostných zákonov, v rámci ktorého (Černík et al., 1987, s. 197) môžeme hovorit’ o dynamickom zákone ako o zákone jednotlivého prípadu a o štatistickom zákone zas ako o zákone masových javov, ako aj o hlbinnej predpokladovosti a nevratnosti biologického evolučného procesu, v ktorom sú budúce udalosti silne determinované alebo limitované udalost́ami (alebo procesmi), ktoré sa $u z ̌ ~ u d i a l i v$ dávnej či nedávnej minulosti. ${ }^{5}$

Pre objektívnost' pritom treba uviest', že na 224. strane ZSM vel'mi tvrdo skritizovali Goulda za jeho jalové polemiky s R. Dawkinsom (ako tvorcom teórie tzv. sobeckého génu; in Flegr, 2005, s. 118-119, 143), sociobiológiou či dokonca celou súčasnou biológiou, ale hned' na tej istej strane začali vyslovene odt'ažito špekulovat' nad tým, či je vôbec pre biologickú evolúciu typické „rozrôzňovanie“, pretože z klasického darvinovského mechanizmu vraj jasne vyplýva, že biologická evolúcia by mala skôr spiet' k optimalizácii, t. j. „k najlepšiemu z možných riešení, než ku vzniku množstva alternatív“; čo je ale v zjavnom rozpore s ich tvrdeniami na 250. strane, kde

\footnotetext{
${ }^{5}$ Aj ked' jedným dychom musíme dodat', že ZSM v tomto nie sú zd’aleka nejakou vzácnou výnimkou, pretože aj taký renomovaný evolučný biológ, akým nesporne bol E. Mayr, počas debaty s nedávno zosnulým C. Saganom v čisto gouldovskom a popperovskom duchu bez zaváhania konštatoval (in Davies, 2001, s. 283), že „na Zemi z miliónov rodových línií organizmov a vari z 50 miliárd prípadov vzniku nových druhov iba jedna cesta viedla k vysokej inteligencii“, vzhl’adom k čomu vraj možno predpokladat', že jej vznik je úplne nepravdepodobný; podsúvajúc tak čitatel'ovi úplne pochybnú a nerealistickú predstavu o biologickej evolúcii, ktorá by v takomto prípade musela akoby nanovo začínat' alebo štartovat' pri každom vzniku nového biologického druhu, čo je hypotéza, ktorá sa, podl’a nášho názoru, musí javit’ ako extrémna každému racionálne uvažujúcemu biológovi.
} 
ZSM konštatujú, že sa skoro zdá, že uvedené „rozrôzňovanie“ druhov „je zákonité, takže by sme ho mohli aspoň do určitej miery predvídat'“, ako aj na 252. strane, kde už ZSM upozorňujú, že ekologické niky do určitej miery existujú akoby dopredu, a tak môžu byt' jednotlivými druhmi postupne „nachádzané“ a vyplňované, ale len preto, a tu už ZSM prechádzajú takmer úplne na platformu strednej usmernenosti biologickej evolúcie, že „všetky druhy podliehajú v danom okamžiku konkrétnym obmedzeniam, ktoré podmieňujú možnosti d’alšej evolúcie“, a (potenciálnych) ník tak musí byt' vždy ovel'a viac ako druhov.

V tomto istom konštruktívnom duchu potom Zrzavý et al. na 271. až 272. strane konštatujú, že jednotlivé rôzne vel'ké vymierania biologických druhov mohli mat' aj svoje vnútorné, teda čisto biologické príčiny (a nielen príčiny geologického alebo mimozemského pôvodu), pretože pri modelovaní zložitých fyzikálnych systémov sa už dávno "zistilo, že s rastom zložitosti systému rastie i pravdepodobnost' jeho zrútenia“, prekvapujúc následne environmentálne "ladeného“ čitatel'a tvrdením (tamže, s. 276), že v trópoch v súčasnosti dochádza skôr k výmene biologických druhov, pri ktorej jednotlivé druhy síce čoraz rýchlejšie vymierajú, ale zároveň aj čoraz rýchlejšie v rámci alopatrickej speciácie vznikajú, ale v závere knihy sa opät' vracajú na staré gouldovské "chodníčky“, konštatujúc (tamže, s. 277-278), že o d'alšom smerovaní evolučných (t. j. už nie bioevolučných - R. B.) procesov nemôžeme nič vediet', aj ked' sú sčasti v našich rukách, že človek sa vraj nevymanil z prírody (ktorá však v celej ich knihe zostala nedefinovaná - R. B.) a vznik civilizácie je súčast'ou opät' bližšie nedefinovaných evolučných procesov ako takých, pretože evolúcia ako taká nemá ciel', čo ale údajne nevylučuje, že v nej retrospektívne môžeme zaregistrovat' určité smerovanie či trendy.

Rovnako biocentrická a „panbiologická“ je aj koncepcia živého, ktorú takmer dvadsat' rokov rozpracúva v úzkej spolupráci so Z. Neubauerom A. Markoš (1997, 2003 a i.), ktorý síce správne a úplne odôvodnene vystupuje proti všetkým pokusom redukovat' živé len na molekulárno-biologické alebo biochemické (1997, s. 12-13), ale zároveň celkom nekorektne pripisuje parametre živého aj neživej prírode, bezvýhradne akceptujúc Lovelockovu (1994, 2007 a i.) hypotézu o existencii Gaie, t. j. celej Zeme ako živej planéty alebo jednotného či jediného planetárneho superorganizmu (resp. v krajnom prípade len jej vrchnej vrstvy), ktorý pružne reaguje na zmeny vesmírneho prostredia a opakovane navodzuje podmienky vhodné pre svoju homeostázu (Markoš, 1997, s. 69), nekorektne rozširujúc a prenášajúc parametre živého aj na sociálno-kultúrne alebo čisto l'udské, a to vo svojej d'alšej knihe (2003, s. 294-295, 324), kde bez rozpakov okrem iného konštatuje, že biologický druh možno prirovnat' ku kultúre, že k vzniku nových druhov alebo kultúr môže dôjst' aj mutáciou textu (DNK), že živé systémy sa od strojov odlišujú svojím zmyslom, vnútornou interpretáciou situácie, uzavierajúc dokonca, že práve rozpracovanie takejto verzie vitalizmu by malo byt́ cielom každého biológa. 
Z. Neubauer vo svojej najznámejšej práci (2002, s. 23) rovnako predpojato konštatuje, že skúsenost' mechanického „vychádza z našej aktivity, ktorá niečo vytvára, predstavuje, napodobňuje“, zatial' čo skúsenost' biologického, "subjektivity naproti tomu spočíva v našej aktivite, ktorá reflektuje, vzt'ahuje sa k sebe, vníma a pocit'uje", opätovne tak ignorujúc alebo zámerne stierajúc principiálny kvalitatívny rozdiel medzi živým a sociálno-kultúrnym (resp. civilizačným). Nemôže nás teda udivit', že podobne ako Markoš aj Neubauer (tamže, s. 242) pripisuje živočíchom schopnost' vytvárat' (si) duševné obrazy či mentálne reprezentácie, volá po navrátení tvarovej príčiny, zámeru a ciel'avedomého účelu do súčasnej biológie (aj ked' dobre vie, že problém vzniku nových biologických tvarov čoraz úspešnejšie rieši tzv. evo- -devo biológia; Carroll, 2010) ${ }^{6}$, či dokonca žiada, aby bol tradičný darvinizmus doplnený, ba v krajnom prípade aj nahradený novou eidetickou biológiou (zahrňujúcou fenomenológiu, estetiku a hermeneutiku živého), ktorá (tamže, s. 249) presúva "svoju pozornost' z úrovne jedincov (telesných realizácií živých foriem) na úroveň podôb (EIDÉ, vzhl'adov, ideí)“, čiže ako sa Neubauer nerozpakuje tvrdit', "na úroveň species (druhov) v pôvodnom slova zmysle“.

V biocentrickej a "panbiologickej" paradigme či "pasci“, t. j. v predstave, že sociálno-kultúrne (a civilizačné) sa vyznačuje len intenzívnejšou realizáciou tých istých parametrov, ktoré evidujeme na úrovni živého ako takého, pritom zostávajú aj viacerí autori v nedávno publikovaných zborníkoch venovaných evolučnej problematike (Nosek-Havlík, 2008; Havlík, Hříbek et al., 2011), a to najmä preto, že na rozdiel od J. Dubničku (1989) a D. Gálika (2009) ignorujú rozdiel medzi biologickou evolúciou a vesmírnou evolúciou, či vývojom ako takým, konštatujúc dokonca, tak ako V. Havlík (Nosek-Havlík, 2008, s. 121-122), že evolučný proces ako taký „má charakter všeobecného a univerzálneho zákona", že by bolo vhodné "preukázat' určité zhody v unifikujúcej, zovšeobecňujúcej, explanačnej a predikčnej funkcii niektorého bežne prijímaného prírodného zákona a evolučného procesu“, a stotožňujúc tak so zákonom samotný evolučný proces, ktorý takýmto zákonom môže byt' len usmerňovaný či riadený, ale v žiadnom prípade nie byt' s ním totožný, ba ponúkajúc čitatel'ovi aj d'alšie, ešte naivnejšie tvrdenie (tamže, s. 122-123), podl'a ktorého je Darwinova evolučná teória neporovnatel'ná s Newtonovým gravitačným zákonom, aj ked' je jasné, že sa tu porovnáva neporovnatel'né. ${ }^{7}$

Ešte horšie je, že Havlík aj nad'alej (Havlík, Hříbek et al., 2011, s. 75-124) zotrváva v tomto omyle a stále sa pokúša presvedčit' čitatel'a, že parametre biologickej evolúcie ako takej môžu byt' bez väčšieho zatemnenia či skreslenia skutočnej ontologickej a epistemickej situácie prenesené na vesmírnu evolúciu či vesmírny

\footnotetext{
${ }^{6}$ Schopná podl'a R. Amundsona (2008) dokonca preklenút' celé 20. storočie otvorenú epistemickú „priepast““ medzi experimentálnou embryológiou a tzv. syntetickou evolučnou teóriou, založenou na populačnej genetike, dôkladne opisujúc a vysvetl'ujúc práve kauzálny mechanizmus vedúci k vzniku nových tvarov alebo orgánov.

${ }^{7}$ Ked’že vedecká teória je súborom rôznych deduktívne alebo induktívne vyvodených výrokov, zatial' čo vedecký zákon je určitým vztahom, ktorý tieto výroky spája, usporadúva, usúvzt’ažňuje alebo systematicky organizuje.
} 
vývoj ako taký, aj ked’ aj jemu samému musí byt' jasné, že o nejakých replikátoroch na úrovni geologického či chemického $\mathrm{v}$ žiadnom prípade nemôže byt' ani reči (kedže atómy a molekuly sa na rozdiel od živých buniek či horehronských alebo krkonošských krásavíc skutočne nerozmnožujú), tvrdiac navyše (tamže, s. 76, 88), že $\mathrm{z}$ hl'adiska súčasnej evolučno-biologickej paradigmy to jediné, čo sa $\mathrm{v}$ priebehu biologickej evolúcie zachováva, "sú alely ako konkrétne formy génov“, pričom nič údajne nebráni tomu, aby evolučný mechanizmus pracoval „vo všeobecných súvislostiach nezávisle na entitách, ktoré sa mu podrobujú“, aj ked’ je zrejmé, že moderná filozofia biológie (Okasha, 2008) nepovažuje problém vymedzenia hlavných úrovní žívého, na ktorých primárne pôsobí prirodzený výber, za zd’aleka uzavretý, zatial čo existencia uvedeného globálneho evolučného mechanizmu zostáva velmi spornou najmä na úrovni nerozmnožujúcich sa neživých systémov.

Na konci tohto temného a zdanlivo nekonečného epistemického "tunela“ však už predsa len začína blikat' jasné svetielko, ktorým je séria štúdií D. Gálika (1996-1997) o teoretických problémoch biologickej evolúcie z pohl'adu filozofie, ked' najmä v prvej jej časti (1996a, s. 88) Gálik celkom správne rozlišuje medzi evolúciou ako teóriou opisujúcou „vznik a evolúciu vesmíru, vrátane evolúcie živých organizmov a sociálnych systémov na Zemi“ a evolúciou v užšom slova zmysle, t. j. ako teóriou biologickej evolúcie, polemizujúc navyše s autormi (tamže, s. 91-92), ktorí tvrdia, že teória biologickej evolúcie je v podstate „len ,idiografickou' vedou, opisujúcou sled historických udalostí odohrávajúcich sa na jednej planéte, poprípade len ,rozprávaním príbehov'", neberúc do úvahy, že teória biologickej evolúcie nielen "hladá a odhal'uje hybné mechanizmy evolučného procesu, jeho hybné zákony“, ale ich aj nachádza na rôznych úrovniach hierarchie živých systémov (či organizmov), zameriavajúc sa zároveň aj na „odhal’ovanie univerzálnych zákonov evolúcie živých organizmov", pričom v rozpore so skeptickými tvrdeniami niektorých filozofov (najmä K. R. Poppera) o jej netestovatel'nosti či tautologickosti dokáže predpovedat' viacero javov na všetkých úrovniach evolučného procesu.

Bohužial', v tretej časti tejto série (1996c, s. 313-315) ani Gálik neprekročil hranice gouldovskej paradigmy a vo vzt́ahu k problému progresívnosti biologickej evolúcie nakoniec zaujal identické stanovisko ako Zrzavý et al., konštatujúc najprv, že hlavným problémom je stanovenie jasných, dostatočných a empiricky overitelných kritérií takéhoto progresu, ktorého vymedzovanie vraj vždy bude poznačené subjektívnymi súdmi a/lebo hodnotením, a následne upozorňujúc (tamže, s. 315), že aj samotný Ch. Darwin vo svojich denníkoch a poznámkach „rozvijal myšlienku o mnohosmerovosti evolúcie, v ktorej je progresívny vývoj náhodným, vedlajším produktom evolučného procesu“", ktorá sa vraj v posledných rokoch začína čoraz viac presadzovat', v dôsledku čoho prestáva byt' progresívny vývoj považovaný za všeobecný zákon evolučného procesu, pričom (tamže, s. 316; podč. R. B.) výnimočnost' postavenia človeka v evolúcii vraj „spočíva v tom, že jeho evolúcia 
odkrýva nové dimenzie evolučného procesu, presahujúce hranice biologickej evolúcie, ktoré sa však zároveň odohrávajú v týchto hraniciach“, čo je ale len d'alšie nekonzistentné tvrdenie, pretože bio-psycho-socio-kultúrny fenomén (akým človek je) nemôže súčasne byt' aj nebyt' len biologicky limitovaným tvorom. ${ }^{8}$

Našt́astie, už v roku 1985 vyšla na Slovensku pozoruhodná kniha sovietskych autorov A. Jablokova a A. Jusufova, v ktorej boli všetky tri nami nastolené problémy, t. j. problém autonómnosti a usmernenosti biologickej evolúcie, jej progresívnej orientácie i zákonitosti, riešené vel'mi konštruktívne vo vzájomnej súvzt́ažnosti a podmienenosti. Dodnes neprekonaná je najmä kapitola o evolučnom progrese (tamže, s. 233-242; podč. A. J. a A. J.), v ktorej sa najprv vyčleňuje tzv. neohraničený progres ako objektívny vývoj "realizovaný v podmienkach Zeme od najjednoduchších živých bytostí až po l'udskú spoločnost' ako sociálnu formu pohybu hmoty" , v rámci ktorého si nakoniec po vzniku človeka začala, Engelsovými slovami, príroda uvedomovat' samú seba, pričom (tamže, s. 234, 235) samotný tento „prechod k vyššej forme pohybu hmoty sa realizoval len v jednej z vývojových vetiev živej prírody“, pretože všetky ostatné "pokusy“ neuvedomenej prírody o vytvorenie sociálno-kultúrneho, ku ktorým došlo napríklad v rámci tzv. obligátnych spoločenstiev hmyzu (včiel, mravcov a termitov) alebo v niektorých skupinách stavovcov (kopytníkov, zubatých vel'rýb a primátov) sa v dôsledku ich nedostatočne rozvinutého sebapoznania museli skončit' a skončili bezvýsledne a neúspešne.

Ešte dôležitejšie je ale ich zistenie (tamže, s. 234), že „v priebehu času sa biosféra stala ovel’a zložitejšou“, a to pre každú v nej existujúcu či novovznikajúcu skupinu organizmov, v dôsledku čoho museli všetky novovznikajúce organizmy (a ich populácie) v rámci akéhosi neustále sa rozširujúceho a zosilňujúceho spätnoväzbového procesu čelit' nielen rastúcej zložitosti tohto čoraz komplikovanejšieho abioticko-biotického prostredia, ale aj (tamže, s. 235) rastúcej konkurencii zo strany ostatných organizmov (a ich skupín či populácií), ktoré sa takýmto čoraz rýchlejšie a viac sa meniacim podmienkam snažili prispôsobit' (väčšinou len čiastočne úspešne a nakrátko) svojou rastúcou špecializáciou a jednostrannou adaptáciou na jeden či len niekol'ko typov prírodného prostredia, rýchlou reprodukciou alebo (relatívne úspešne) čo najuniverzálnejšou adaptáciou na najrôznejšie typy prírodného prostredia, ako môžeme sledovat' nielen u teplokrvných a čoraz inteligentnejších cicavcov, ale aj u vtákov, schopných vd'aka svojej extrémnej pohyblivosti zaberat' čoraz väčšie životné areály, ale nie u človeka,

\footnotetext{
8 Človek sa teda nielenže môže postupne zbavit’ svojej biologickej určenosti, ked’že nie je takým istým produktom biologickej evolúcie ,ako každý iný živý organizmus“ (tamže), ale sústavne a čoraz úspešnejšie sa o to vytváraním svojho umelého civilizačného prostredia a epistemickým prenikaním do podstaty organizácie živého aj usiluje, v dôsledku čoho sa ocitá mimo biologického evolučného radu a svojím rozvojom navyše vytvára podmienky nie pre vznik nejakých d'alšich organizmov, ako mylne tvrdí D. Gálik, ale úplne novej, nadsociálnej formy pohybu hmoty, ako odôvodnene tvrdíme my vo viacerých našich textoch (2010b, 2011).

${ }^{9}$ Nami nedávno detailne vymedzenú najprv v E-LOGOSE (Burgan, 2010b) a potom aj inde (Burgan, 2011).
} 
ktorý sa skutočne a definitívne vymanil zo živej prírody práve vtedy, ked' si začal sám vytvárat' svoje civilizačné prostredie a ovel'a neskôr aj usmerňovat' svoj vlastný vývoj. ${ }^{10}$

Pri biologickom progrese zas viac vystupujú do popredia čisto kvantitatínne parametre, kedy sa úspešnost' tej či onej skupiny organizmov meria počtom do nej patriacich jedincov, ktorí tento svoj momentálny úspech môžu dosahovat' nielen väčšou zložitost'ou (ako tomu bolo pri neohraničenom progrese), ale aj (tamže, s. 236) „zjednodušením organizovanosti“ či dokonca prechodom k parazitnej forme existencie, t. j. prechodom „od aktívnej formy výživy k pasívnej, od pohyblivého spôsobou života k prisadnutému“, pri ktorom sa „u organizmov redukujú orgány, ktoré majú aktívnu funkciu (končatiny, nervová sústava, korene, listy a i.), ale vel'mi sa vyvíjajú také orgány, ako bradavky, prísavky, rozmnožovacia sústava“. Kedže sa však pri takejto forme adaptácie viac jedná o prispôsobenie sa biotickému ako abiotickému (či abioticko-biotickému) prírodnému prostrediu, Jablokov a Jusufov navrhujú aj d'alšie, ovel'a objektívnejšie kritérium biologického progresu, na základe ktorého sa biologická úspešnost' tej či onej skupiny organizmov definuje dosiahnutým stupňom ekologickej prosperity daného biologického taxónu porovnávaním rozmerov jeho areálu a počtu poddruhov, druhov, rodov či radov v jeho rámci, čím sa vyjadruje (tamže, s. 237) úspech danej skupiny v existenčnom boji.

Nakoniec pri skupinovom progrese sa berie do úvahy (tamže, s. 238-239; podč. A. J. a A. J.) „zdokonalenie plánu štruktúry (alebo telesnej stavby - R. B.) v procese evolúcie vel'kej skupiny", ked' sa pri vyšších rastlinách ako prejavy skupinového progresu uvádzajú „zosilnenie primknutosti k substrátu, prechod vedúcej úlohy v ontogenéze ksporofytu, vznik cievnych zväzkov atd'." a pri cicavcoch ako vyhranenej progresívnej skupine zas živorodost', stála telesná teplota, vznik dokonalej termoregulácie, určitá stavba zubov, lebky a špecifický vývoj mozgu ako znaky, ktoré v rozličnej miere existujú aj u niektorých skupín plazov, ale iba u cicavcov ako osobitne výhodné adaptácie jasne poukazujú na úzku súvislost' skupinového progresu s biologickým; zatial' čo pri biotechnickom progrese vystupuje do popredia nielen sústavne zdokonal'ovanie sa zmyslových orgánov zhl'adiska presnosti a rozsahu ich funkcií, ale aj tzv. koeficient užitočnej činnosti orgánov (objavený V. Francom), uplatňujúci sa pri cicavcoch aj prechodom od chodenia na celom chodidle (ako je tomu u väčšiny plazov) k ovel'a pružnejšiemu a rýchlejšiemu pohybu na prstoch a zároveň jasne ukazujúci, aký vel'ký význam má v biologickej evolúcii zaujatie novej adaptínej zóny s bohatými zdrojmi potravy. ${ }^{11}$

Nemenej pozoruhodné sú však aj Jablokovove a Jusufovove názory (tamže, s. 263277) na celkovú usmernenost', ba až zákonitý priebeh plne autonómneho

\footnotetext{
${ }^{10}$ Napríklad v rámci dnes tak vášnivo diskutovaných experimentov s l'udským genómom či genofondom.

${ }^{11}$ Nie však dlhodobo stabilnej a homogénnej adaptívnej zóny, ako tomu nasvedčuje príklad delfínov (tamže, s. 241), ktoré síce majú mozog, „ktorý podl’a mnohých morfologických osobitostí prevyšuje l’udský mozog“, ale v relatívne stabilnom a homogénnom vodnom prostredí sa jednoducho nemajú ,ako“ a „kde“ d’alej rozvíjat'.
} 
biologického evolučného procesu, kedy obaja autori na jednej strane odmietajú rôzne formy „nedarvinovskej“ evolúcie, akými sú napríklad selektívna neutralita malých mutácií či neadaptačný charakter zmien postupnosti aminokyselín v molekule hemoglobínu u niektorých stavovcov, a na strane druhej rovnako vehementne vyvracajú aj Bergovu nomogenetickú koncepciu (tamže, s. 265), podl'a ktorej „sa evolúcia nerealizuje na základe náhodne vznikajúcich dedičných odchýlok, ako predpokladal Ch. Darwin, ale na základe realizácie istých vnútorných zákonov“, zdôrazňujúc (tamže, s. 268; podč. A. J. a A. J.), že základom usmerňovania biologickej evolúcie je jednak „usmernené pôsobenie prírodného výberu v priebehu vel'kého počtu pokolení,, jednak systém zákazov podmienený tak morfologicko-fyziologickou organizovanostou, ako aj genotypovými osobitostami danej skupiny, ktoré napríklad nedovolujú žralokom, aby žili v sladkých vodách, a dodávajúc, že súčasná biológia nielenže nezavrhuje, ale naopak vyzdvihuje jav usmernenosti ako nevyhnutný dôsledok darvinovského chápania celkového „charakteru priebehu evolúcie“.

Bokom by sme nemali ponechat' ani ich vymedzenie populácie (tamže, s. 99-100) ako elementárnej evolučnej jednotky, čiže spoločenstva jedincov určitého druhu, ktorí spolu žijú dlhší čas a od ostatných spoločenstiev sú oddelení rozličným stupňom panmixie a príslušného stupňa izolačného tlaku, a elementárneho evolučného javu (tamže, s. 110-112) ako zmeny genotypového zloženia populácie, ku ktorej dochádza pod tlakom mutačného procesu, ale vo vel'kej miere aj vplyvom kombinatoriky, „rekombinácie genotypov v procese crossing-over“, ktorý podl'a autorov ešte nie je evolučným procesom v pravom slova zmysle, ale na druhej strane je už natol'ko dlhodobou a zasmerovanou zmenou populačného genofondu, že „už na tejto najnižšej úrovni je proces evolúcie nevratný", stávajúc sa zároveň ideálnym nástrojom na vymedzenie a vzájomné porovnávanie efektívnosti jednotlivých elementárnych evolučných činitel'ov (tamže, s. 113-126), vrátane mutačného procesu, populačných vín či priestorovej a biologickej izolácie, najmä však samotného prirodzeného (alebo prírodného) výberu ${ }^{12}$ ako hybnej sily evolúcie, či už vo forme (tamže, s. 140-146) stabilizujúceho, disruptívneho, hybného, pohlavného, individuálneho a skupinového, alebo hustotne závislého r-a K-výberu.

A najmä nie ich analýzu vzájomného vztahu medzi práve opísanou mikroevolúciou a makroevolúciou, prebiehajúcou na druhovej a naddruhovej úrovni (tamže, s. 184, 274-275), v rámci ktorej A. Jablokov a A. Jusufov odmietajú všetky „predstavy, podl'a ktorých procesy a zákonitosti makroevolúcie akoby neobjasnené vychádzali z mikroevolučnej teórie“, ked’že vznik rodov, radov, čel'adí atd'. "musí“ prebiehat' „na základe principiálne odlišných činitel'ov a zákonitostí, neprejavujúcich sa na populačno-druhovej úrovni“, konštatujúc, že stúpenci tohto náhl'adu nepredložili žiadne vierohodné prírodovedecké fakty, ktoré by ho potvrdzovali,

\footnotetext{
${ }^{12}$ Pojem „prirodzený výber“ používame v tejto práci zámerne, rozlišujúc medzi ním a „prírodným výberom“ ako triediacim procesom, ktorý sa nerealizuje len na úrovni živého, ale aj v rámci prírody ako koherentného celku.
} 
a podotýkajúc, že pri dnešnej (presnejšie, vtedajšej - R. B.) úrovni našich vedomostí nemáme žiadny dôvod vyčleňovat' špeciálnu makroevolučnú úroveň organizácie života, pretože „všetky makroevolučné fenomény sa napokon skladajú z mikroevolučných javov a udalostí", čo sa nám ale nezdá byt', jemne povedané, v úplnom súlade s nimi predtým dokázanou existenciou (tamže, s. 201-206) viacerých pravidiel evolúcie skupín ${ }^{13}$ či dokonca ich vlastnými tvrdeniami (tamže, s. 273-274) o evolúcii samotných evolučných mechanizmov vo vel'kých taxónoch a rastúcej úlohe správania (vzájomnej pomoci, sútaženia, hier atd’.) najmä v evolúcii zvierat.

Viac svetla práve do tejto problematiky nakoniec vnáša V. Stanko $(1987,1989)$, ktorý už vo svojej prvej štúdii z roku 1987 ešte dôslednejšie využíva dialektickomaterialistickú epistemickú metódu, upozorňujúc, že Engelsovým vymedzením základného biologického protirečenia ako protirečenia medzi dedičnost́ou a prispôsobovaním sa pred nami otvára cesta nielen $\mathrm{k}$ jeho dodnes neprekonanej definícii života (tamže, s. 728; podč. R. B.) ako spôsobu existencie bielkovín, ktorý „väzí $\mathrm{v}$ podstate v neprestajnom sebaobnovovaní elementárnych zložiek týchto (bielkovinových R. B.) zlúčenín", ale aj k určeniu skutočnej progresívnej orientovanosti biologickej evolúcie, prejavujúcej sa najmä v raste autonomizácie organizmov, a poukazujúc najprv spolu s A. Severcovom (tamže, s. 729-731) na neustály rast zložitosti biologického prostredia, vynucujúci si následne v rámci adaptačných procesov aj primerane zložitejšie usporiadanú stavbu organizmov, a potom aj na postupnú univerzalizáciu „životnej činnosti biologických organizmov“, vyúst'ujúcu do ich rastúcej autonomizácie, ktorú si však „nesmieme predstavovat' ako odtrhnutost” od prostredia", ale ako "postupné zdokonal'ovanie vzt'ahu živého systému s prostredím", pri ktorom d'alej vzrastá úloha vnútorných faktorov. ${ }^{14}$

Ako v tejto súvislosti vzápätí zdôrazňuje V. Stanko (tamže, s. 732), „posledným krokom takéhoto sebazrušenia prírodného výberu je premena predchodcu človeka na človeka“, vo svojej podstate analogická sebazrušeniu neživej prírody pri vzniku genetického kódu a života samého, ako logický výsledok biologického evolučného procesu, počas ktorého prirodzený výber (tamže, s. 734) „od začiatku ,ruší sám seba tým, že neustále vytvára autonómnejšie druhy, teda druhy, na ktoré čoraz menej dolieha jeho vplyv“, uzavierajúc svoju štúdiu vecným konštatovaním, že "takáto interpretácia teórie prírodného výberu zahrnuje mikroevolúciu (tvorba nových druhov) aj makroevolúciu (celostnost' života zahrnujúca integráciu druhových populácií)“, čo mu umožňuje odmietnut' rast negentropie ako podstatnú črtu evolúcie života a namiesto neho (t. j. namiesto tohto redukcionistického, čisto

\footnotetext{
${ }^{13}$ Ako sú Dollovo (1893) pravidlo nevratnosti evolúcie, Déperovo (1976) pravidlo progresívnej špecializácie a i.

${ }^{14}$ Ako zretel'ne vyplýva napríklad z vývoja nervových štruktúr (ba aj samotného mozgu; tamže, s. 731), ktoré „súvisia so špecializáciou výlučne tým, že sú špecializované na univerzálny typ životnej činnosti“, zatial” čo mozog prednostne „kontroluje telesné ústroje“ a vymedzuje ich vzt’ah k čoraz zložitejšiemu vonkajšiemu svetu.
} 
energetického či organizačného kritéria biologického evolučného progresu) $)^{15}$ ponúknut' práve viackrát spominané kritérium rastúcej autonomizácie živého, zohl'adňujúce prednostné pôsobenie prirodzeného výberu na úrovni mikroevolúcie a následne aj makroevolúcie, kde však už prirodzený výber nevystupuje len ako d'alej sa reprodukujúca causa sui, ale aj ako princíp, ktorý čoraz viac ruší aj sám seba.

Takémuto chápaniu (či riešeniu) danej problematiky zostáva Stanko verný aj vo svojej štúdii z roku 1989, kde hned' v úvode konštatuje (tamže, s. 711), že ",ak za kritérium progresu budeme považovat' prispôsobenie sa organizmu svojim životným podmienkam, ostáva pre nás nezodpovedatel'nou otázka, či je progresívnejší vírus alebo človek", dodávajúc navyše, že ak za kritérium progresu budeme namiesto toho považovat', tak ako to urobil on sám vo svojej predošlej štúdii, „stupeň zložitosti stavby tela a stupeň univerzalizácie organizmu vo vzt́ahu k prostrediu“, zostane „pre nás záhadou, čo túto zložitost’ a zodpovedajúcu univerzalizáciu podmieňuje“. Ako d'alej podotýka (tamže, s. 712), riešenie tohto problému „je možné len z platformy prekračujúej druhocentrické hl'adisko skúmania“, kedy berieme do úvahy, že populačno-druhová úroveň môže zodpovedat' len za tú "nevyhnutnost”, sktorou vznikajú nové biologické druhy", zatial" čo otázku nevyhnutnosti progresívneho vývinu živej prírody možno riešit' len na jej nadradenej biocenotickej úrovni, pretože „iba biocenóza môže vystupovat’ ako tá jednota protikladov, ktorých riešenie naplňuje obsah pojmu progresívna evolúcia“, ked'že až na jej úrovni sa vynára problém „vzájomného spolužitia organizmov rozličných druhov“.

To ale znamená (tamže, s. 713), „že nie úroveň populácie, ale prinajmenšom úroveň biocenózy nám môže byt' východiskom pre vedecké zdôvodnenie tej nevyhnutnosti, s ktorou dochádza k progresu, t. j. k sebanegácii živej prírody“, z čoho zas vyplýva, že biologický evolučný proces ako taký nie je predovšetkým adaptaciogenézou, t. j. prispôsobovaním sa jednotlivých organizmov abiotickobiotickému prostrediu v rámci ich druhu, ale skôr a viac vzájomným spolužitím a sút'ažením rozličných druhov organizmov v rámci biocenóz (alebo biogeocenóz - R. B.), ich a najmä jeho vnútornou aktivitou, v rámci (a počas) ktorej sa od prvej chvíle vytvárajú predpoklady na vznik vyššej a/lebo d'alšej formy pohybu hmoty, t. j. človeka ako sociálno-kultúrnej bytosti, „ktorá sa vonkoncom nespráva iba adaptívne“. Až vtedy teda, ked' prestaneme chápat' vzájomné vzt́ahy medzi druhmi $\mathrm{v}$ biogeocenéze len ako ich jednoduchú koexistenciu a namiesto toho si začneme všímat' aj ich vzájomné príčinné pôsobenie, budeme môct' preniknút k vlastnému obsahu, k skutočnej podstate a dynamike biologického evolučného procesu, ktorého východiskové protirečenie medzi dedičnost'ou a prispôsobovaním môže byt' a aj je vyriešené až na nadbiologickej sociálno-kultúrnej úrovni.

\footnotetext{
${ }^{15}$ Presadzovaného (tamže, s. 735) najmä L. Boltzmannom, podla ktorého je život „vývoj smerujúci k narastaniu antientropických procesov na úkor energie Slnka“, a dodnes tradovaného najmä v populárno-náučnej literatúre.
} 
Reálne rozpory biogeocenózy, ako d'alej upozorňuje V. Stanko (tamže, s. 714; podč. R. B.) sú tak „neriešitel'né v rámci Darwinovej teórie prírodného výberu“, pretože „abstraktne všeobecné, čiže to, že chrípkový vírus, dážd'ovka, vlk či delfín sú adaptáciou, ešte nevytvára polárny protiklad chrípkového vírusu a vlka, protiklad dážd’ovky a delfína, čiže protiklad špecializovaného a univerzálneho". Tento protiklad totiž vystupuje do popredia až na úrovni rozšírene sa reprodukujúcej biogeocenózy ako takého systému podmienok (tamže, s. 715), „v ktorom nevyhnutne vznikajú dva javy: morfofyziologický progres a morfofyziologický regres, ktoré sa súčasne navzájom aj vylučujú, aj predpokladajú“, pričom jednotlivé určenia morfofyziologického progresu (univerzálnost', relatívna autonómnost', jednoduchá zložitost' stavby tela a i.) stoja vopozícii voči jednotlivým určeniam morfofyziologického regresu (t. j. špecializovanosti, závislosti a zložitej jednoduchosti); na základe čoho už môžeme definitívne konštatovat', že Stankov zákon progresívnej biologickej evolúcie $^{16}$ (tamže, s. 716) čoraz viac nakláňa pomyselné misky argumentačných váh na stranu tých, ktorí sú presvedčení o strednej usmernenosti, principiálnej opakovatelnosti a zákonitosti biologického evolučného procesu.

\section{Prečo musí byt' a je biologická evolúcia len stredne usmerneným procesom}

V druhej časti nášho článku mienime jednoznačne preklopit tieto pomyselné váhy na stranu obhajcov idey progresu vbiologickej evolúcii, jej principiálnej opakovatel'nosti, zákonitosti a strednej usmernenosti, predstavujúc najprv niekol'ko súčasných štúdií, v ktorých sú detailne diskutované a vysvetl'ované vyššie uvedené myšlienky, a uzavierajúc celý náš článok nielen niektorými menej známymi, ale o to dôležitejšími globálno-evolučnými koncepciami, ale aj a predovšetkým - našou vlastnou globálno-evolučnou koncepciou, v rámci ktorej dôsledne rozlišujeme (Burgan, 2010a, 2011, 2012) medzi vývojom vesmíru, vývojom vo vesmíre a multivesmírnym vývojom v pravom slova zmysle. Prvý text, s ktorým sa oboznámime, bude text $\mathrm{B}$. Rosslenbroicha (2009), ktorý sa čitatel'ovi oboznámenému so Stankovými textami možno bude javit' akoby bol práve na Stankovu objednávku napísaný, pretože hned' v jeho úvode (tamže, s. 623) sa doslova šokovaný čitatel’ z bývalého Východného bloku dozvedá, že najdôležitejšie evolučné inovácie v ríši živého spočívajú vo vzraste autonómnosti organizmov „v zmysle ich emancipácie od okolitého prostredia“, v rámci ktorej sú postupne redukované priame vplyvy z tohto prostredia a stabilizujú sa špecifické, „intrinzické“ funkcie organizmu.

\footnotetext{
${ }^{16}$ Zohl'adňujúci nielen dialekticky protirečivý vzt’ah špecializovaného a univerzálneho v biologickej evolúcii či generálnu líniu morfofyziologického pokroku od zložitej jednoduchosti k jednoduchej zložitosti, ale aj kruhové (a teda nie jednosmerné kauzálne) pôsobenie medzi biologickými druhmi a ich vonkajším abiotickým prostredím, v rámci ktorého (tamže, s. 715) jednotlivé organizmy do seba čoraz viac integrujú komplexnost' svojho čoraz zložitejšieho abioticko-biotického prostredia a vyvíjajú sa tak v smere svojej vlastnej sebanegácie a prekonania.
} 
Ako d'alej pokračuje B. Rosslenbroich, tento vzrast autonómnosti organizmov počas biologickej evolúcie sa prejavuje vo vzraste ich priestorovej pohyblivosti (alebo dištančnosti), telesnej vel’kosti, v rozvoji a internalizácii ich homeostatických funkcií a sústavnom vzraste ich fyziologickej a behaviorálnej pružnosti (či flexibility), ako sa môžeme l'ahko presvedčit' pri pohl'ade na celú evolúciu od prokaryot, cez prvé mnohobunkové organizmy až po primáty, začínajúce manipulovat' so svojím vonkajším prostredím a prenášat' nadobudnuté skúsenosti aj inak ako len cez dedičné mechanizmy či inštinktívne napodobňovanie. Podl'a nemeckého biológa (tamže, s. 624) sa pritom až do dnešného dňa nenašiel nikto, kto by systematicky skúmal práve ním vymedzený princíp vzrastu autonómnosti organizmov počas biologickej evolúcie, čo je však podl'a nás nie celkom legitímne konštatovanie, aj ked' pri zaužívanej ignorácii všetkého, čo nie je napísané po anglicky, úplne pochopitel'né, pretože analogicky ako B. Rosslenbroich uvažoval, ako sme mohli vidiet', nielen V. Stanko, ale aj M. Skalský (1991, s. 80-82), spájajúci vývin ako taký s rastom miery sebaurčovania akéhokol'vek systému, a najmä B. Poršnev (1979), uvažujúci o tomto princípe s ešte väčším časovým predstihom. ${ }^{17}$

Ovel'a dôležitejšie ako všetky otázky ohl'adom bádatel'skej priority je však nasledujúce Rosslenbroichovo konštatovanie, podl'a ktorého „neexistuje žiadny všeobecný kontinuálny trend smerom k autonómii: mnohé línie sa vyznačujú touto črtou v rôznej forme a nezávisle jedna od druhej “18, naznačujúce, že ide skutočne o všeobecný evolučný trend v tom slova zmysle, že sa opakovane a nezávisle objavuje na všetkých úrovniach vyvíjajúceho sa živého, a ešte viac Rosslenbroichovo precízne vysvetlenie a "zdokumentovanie“ daného evolučného princípu, začínajúce sa (tamže, s. 626-627) už na tej najelementárnejšej úrovni, t. j. na úrovni prokaryotickej bunky, ktorej bunečná membrána oddel'uje jej vnútorné prostredie od okolitého abiotického a biotického prostredia, vytvárajúc internalizovaný celok (angl. compartment) s vlastnou fyziologickou reguláciou a spotrebou energie, autonómne fungujúci a vyvíjajúci sa aj pomocou dedičných mechanizmov, a ako taký principiálne sa líšiaci od všetkých foriem neživej (alebo anorganickej) hmoty, čo vo svojom súhrne, ako podl'a nás celkom správne zdôrazňuje Rosslenbroich, robí vel'mi

\footnotetext{
${ }^{17}$ Konštatujúc napríklad (tamže, s. 287-288), ako zdôrazňujeme aj v našom predošlom článku (Burgan, 2012), že pohyblivost' alebo ,pohyb vyššieho živočícha je vyhnutím sa vnútenej kontaktnej reaktivite, inými slovami, je jej útlmom. Sme príliš pripútaní k l’udskému sebapozorovaniu, preto si aj u zvierat omnoho viac všímame to, čo sa podobá ,ciel'u', ,usilovaniu sa', hoci technika reagovania v evolúcii živej evolúcie sa vyvíjala iba ako veličina odvodená od rozvoja techniky nereagovania, t. j. vylúčenia, odvrátenia, potlačenia jednoduchšej reaktivity“; čo však bolo spojené $s$ rastúcimi energetickými výdavkami všetkých takto sa vyvíjajúcich organizmov; a dodávajúc, že o univerzálnosti tohto „sebaurčovacieho“ či ,,autonomistického“ trendu sa môžeme následne presvedčit’ aj na úrovni sociálnej formy pohybu hmoty (tamže, s. 288; podč. R. B.), kedy: „Stačí ak si všimneme, v akej miere človek prevyšuje zvieratá, aká je jeho dnešná schopnost' premiestňovat' sa, do akej miery sa rozšírila dištančnost' jeho recepcie (informácií): skúsenost’ou predkov, informačnou komunikáciou súčasníkov, individuálnym vybavením, nakol'ko - takmer neobmedzene - sa aparátom jazyka a vedy rozčleňuje a analyzuje okolitý svet."“

${ }^{18}$ V origináli: ,There is not a general continuos trend towards autonomy: many lineages exhibit this feature in different forms and independent of each other." Preklad R. B.
} 
podozrivými všetky pokusy redukovat' biológiu na fyziku a chémiu, opakovane sa objavujúce vo filozoficko-biologickej literatúre (Elgin, 2010 a i.).

Ako je navyše zrejmé (tamže, s. 628), nie všetky druhy organizmov sa vyznačujú touto autonómiou v rovnakej miere, pretože popri organizmoch, ktoré viac podliehajú priamym fyzikálnym, chemickým či biologickým vplyvom zo svojho prostredia, existujú aj organizmy, ktoré sa dokážu správat' viac vo vlastnom "záujme“, pretože sú aktívnejšie, flexibilnejšie či „výberovejšie“ (ako tvrdil už Poršnev, 1979, s. 287-288) vo svojich interakciách s vonkajším prostredím; čo jasne potvrdzuje aj sústavný rast vel'kosti jednotlivých organizmov počas evolúcie, ktorý je pre ne výhodný najmä preto, lebo zmenšuje celkový povrch tela v pomere k jeho objemu a väčším organizmom tak umožňuje reagovat' s vonkajším abioticko-biotickým prostredím ovel'a sprostredkovanejšie (a teda autonómnejšie), ako je tomu najmä u baktérií a iných jednobunkových organizmov, pretože väčšie a objemnejšie mnohobunkové organizmy tak majú lepšie možnosti skladovat' v sebe zásoby energie a dôležitých substancií či vytvárat' si komplexné vnútorné riadiace štruktúry, a v dôsledku toho aj ovel'a lepšie odolávat' náhlym zmenám ich životného prostredia. Rovnaký progres však evidujeme aj na genomickej úrovni, kde práve genetická informácia umožňuje prokaryotám "postavit" ${ }^{\prime \prime}$ poriadok oproti chaosu. ${ }^{19}$

Na úrovni eukaryotickej bunky (tamže, s. 629-630) už môžeme sledovat' podstatné obmedzenie vol'nej výmeny genetického materiálu (napríklad v rámci tzv. horizontálneho génového transferu) v porovnaní s prokaryotickými bunkami, čo eukaryotám umožňuje d'alej stabilizovat' genomickú odolnost' či „svojbytnost"“ (angl. self-assertion) tak na individuálnej, ako aj druhovej úrovni. Pri samotnom prechode na mnohobunkovú úroveň, ktorý sa podl'a Wagonera (2001; tamže, s. 630) uskutočnil nezávisle niekol'kokrát (čo len znova potvrdzuje, že Rosslenbroichom skúmaný proces rastúcej autonómnosti organizmov nie je lineárny), sa zas bunky a orgány integrovali do útvarov s ovel'a väčším homeostatickým potenciálom, čoho dôsledkom je aj vel'ký evolučný rozptyl živočíchov na počiatku kambrickej epochy; zatial' čo pri prechode živočíchov na súš opät' vzrástla ich autonómnost' najmä preto, že si po vyčlenení sa z vodného prostredia pomocou cirkulačných mechanizmov dokázali udržat' svoje "vodné prostredie“, svoj interný "rybníček" v pôvodne nehostinnom a život ohrozujúcom suchom prostredí. K d'alšej stabilizácii homeostázy potom došlo pri prechode na vnútornú tepelnú reguláciu (tamže, s. 633), čo umožnilo predovšetkým vtákom a cicavcom zaujat' nové habitaty.

Nemenej významný bol vznik strunovo-myomérového systému, ktorý poskytol najmä strunovcom možnost' rýchlo plávat' a šprintovat', vytvárajúc zároveň predpoklady pre vznik pevnej kostry a k nej pripojenej svalovej sústavy u stavovcov, schopných vd'aka tomu rýchlo sa vzdialit' zo svojho bezprostredného prostredia,

\footnotetext{
${ }^{19}$ Poskytujúc jednotlivým prokaryotám a ich druhom zároveň aj ich „východiskovú“ identitu a autonómiu.
} 
pohotovejšie reagovat' na rýchlo sa meniacu situáciu a po vzniku endotermie, resp. vnútornej tepelnej regulácie (tamže, s. 634) v prípade potreby okamžite reagovat' na rizikovú situáciu či ohrozenie dodatočnou zvýšenou aktivitou. Menej dôležitý sa napokon zdá byt' vznik amniotického (t. j. zárodočnou blanou vybaveného) vajca u plazov, ktorý im umožnil realizovat' ich reprodukciu mimo nebezpečného vodného prostredia, nasledovaný neskôr d'alšou internalizáciou reprodukčného procesu u živorodých organizmov a cicavcov, ale aj tento evolučný "krok“ je spolu s rozvojom nervovej sústavy (či mozgu) len d'alším dôkazom správnosti Rosslenbroichovho tvrdenia (tamže, s. 638) o nutnosti vyhl'adávat' a definovat' "vel'ké zákony“ života a jeho evolúcie, ako aj jeho kritického vztahu ktradičnej adaptacionistickej paradigme (tamže, s. 640), prezentujúcej organizmy ako pasívne produkty vonkajších evolučných faktorov, bez akejkol'vek vnútornej kompetencie a autonómie.

Priamo ku Gouldovej východiskovej hypotéze o principiálnej neopakovatel'nosti alebo jedinečnosti pozemskej biologickej evolúcie sa vo svojej nedávnej štúdii vyjadruje D. Turner (2011), konštatujúc najprv, že posledný kritik tejto hypotézy - J. Beatty (2006) - celkom správne rozlišuje (Turner, 2011, s. 65-66) medzi dvomi významami pojmu "kontingencia“ u Goulda, a to vo vzt'ahu k možnostiam predikcie a kauzálnej závislosti (alebo súvislosti) biologických fenoménov. Podl'a Beattyho sú pritom obidva tieto významy komplementárne, s čím sa Turner stotožňuje len čiastočne, poukazujúc na to, že Gould nie úplne korektne a plne reflektovane prenáša pojem stochastických efektov, konkrétne náhodného genetického driftu, z mikrovevolučnej úrovne na makroevolučnú, ale bez toho (tamže, s. 66), aby ponúkol dostatočne silné argumenty pre tvrdenie, že biologická evolúcia je kontingentná (či náhodná) v takomto silnom slova zmysle, t. j. aj na makroevolučnej úrovni, a to bez ohl'adu na jeho predošlé poznatky získané pri počítačovom modelovaní makroevolučných procesov v rámci MBL-skupiny, zahrnujúcej nielen Goulda, ale aj D. Raupa, J. Sepkoskiho či T. Schopfa, ktoré (tamže, s. 69-70) naznačujú, že na makroevolučnej úrovni skutočne nepôsobia žiadne zákony.

Podr'a Goulda i Beattyho (tamže, s. 67) sú teda všetky mimoriadne zložité živé systémy vo svojom d'alšom vývoji len slabo závislé na počiatočných podmienkach, ktoré viedli $\mathrm{k}$ ich vzniku, pričom $\mathrm{v}$ samotnej biológii neexistuje žiadny zákon alebo princíp, ktorý by ich nútil vyvíjat' sa predvídatel'ným spôsobom, pretože prirodzený výber (tamže, s. 68) nemá žiadny vplyv na dlhodobejšie evolučné trendy, ako tomu nasvedčuje aj Gouldov slávny výskum tzv. kambrickej explózie živého, v rámci ktorej sa vytvorili mnohé dodnes pretrvávajúce telesné stavebné plány (alebo vel'ké biologické taxóny), ale bez toho, aby prirodzený výber "určil“ či (pre)determinoval, ktoré z nich pretrvajú a ktoré naopak zaniknú. Pri neexistencii žiadneho kauzálne dostatočne silného zákona (aký predložil napríklad V. Stanko), ktorý by na rozdiel od prirodzeného výberu pôsobil aj na makroevolučnej úrovni, nám tak podl’a Goulda nič nebráni predpokladat', že pri teoretickom zopakovaní celého evolučného 
procesu od kambria až po dnes by namiesto v súčasnosti existujúcich telesných stavebných plánov (či vel'kých biologických taxónov) na Zemi prevládali práve tie bizarné telesné stavebné plány (či vel'ké biologické taxóny), ktoré počas kambria milióny rokov prekvitali, ale nakoniec úplne vymizli.

Pokial' ide o samotné príčiny tejto principiálnej stochastickosti a nepredvídatel'nosti makroevolučného procesu, Beatty (tamže, s. 68) predpokladá, že spočívajú v konkrétnom usporiadani alebo časovom poradí jednotlivých mutácií, ktoré by pri teoretickom zopakovaní sa celého makroevolučného procesu od kambria až po dnes nikdy nemohli prebehnút' alebo vyskytnút' sa tak, ako tomu bolo počas jedinečnej pozemskej biologickej evolúcie, zatial' čo Turner sa nakoniec predsa len prikláňa k už uvedenej Gouldovej predstave o analogickej usmernenosti vývojových procesov na evolučnej mikro- i makroúrovni pomocou náhodného genetického driftu, pripomínajúc však (tamže, s. 69, 72-73), že samotný Gould chápal túto náhodnost' makroevolúcie v striktne vedeckom slova zmysle ako stochastickost' všetkých mikroa makrovevolučných procesov, ktorá môže vygenerovat' predpovedatelné usporiadanie alebo „vzory" (angl. patterns), a poukazujúc na zriedka zohl'adňovaný rozdiel medzi tzv. ovplyvnenými (angl. biased) a neovplyvnenými (angl. unbiased) makroevolučnými trendmi napríklad vo forme druhového výberu, ktorý je podla jednej skupiny bádatel'ov „riadený“ určitými faktormi, zatial’ čo podl'a Turnera a Goulda viac-menej náhodný či stochastický. ${ }^{20}$

To by ale znamenalo, že v druhovom výbere nakoniec nevítazia lepšie alebo zdatnejšie biologické druhy, ale tie št́astnejšie, s čím by sa možno radi stotožnili notorickí stávkari, ale v biológii, tak ako v každej serióznej vede, má mat́ posledné slovo pozorovanie či starostlivo kontrolovaný experiment, a tu sa náhle karta začína obracat', pretože ako d'alej uvádza Turner (2011, s. 74-76), v nedávnej minulosti sa skutočne realizovali experimenty, počas ktorých napríklad Lenski a Travisano (1994) a Travisano et al. (1995) zistili, že jednotlivé populácie baktérie Escherichia coli sa bez ohl'adu na rozdielne počiatočné podmienky identicky vyvíjali v d'alej či neskôr modifikovaných podmienkach a (ich) evolúcia sa teda presne zopakovala, pričom na naddruhovej úrovni niečo vel'mi podobné pozorovali Losos et al. (1998) pri malých jašteričkách rodu Anolis, žijúcich v „identickom“ prostredí (napríklad v korunách stromov) na ostrovoch Hispaniola, Kuba, Portoriko a Jamajka, ktoré sú navzájom ovel'a príbuznejšie, a to aj geneticky, ako s ostatnými jašteričkami tohto rodu na uvedených ostrovoch, ani nehovoriac o Conway Morrisom predložených dôkazoch evolučnej

\footnotetext{
${ }^{20}$ Vo svojej staršej štúdii (Turner, 2009) pritom Turner, nadväzujúc na pôvodné práce D. McSheu (1994) prísne rozlišuje medzi tzv. pasívnymi a aktívnymi (alebo dynamickými - angl. driven) makroevolučnými trendmi, konštatujúc (tamže, s. 342), že pasívne trendy sú jednak neovplyvnené (unbiased), t. j. vyplývajú z procesov, $\mathrm{v}$ ktorých je vzrast alebo pokles určitej premennej (ako je napríklad telesná vel'kost') rovnako pravdepodobný, jednak ohraničené (angl. bounded), čiže reprezentované procesmi s hornou a dolnou hranicou premennej, zatial' čo aktívne trendy sú naopak ovplyvnené (biased), t. j. rezultujú z procesov, v ktorých je vzrast jednej premennej pravdepodobnejší ako jej pokles a naopak, bez ohl'adu na to, či sú popritom ohraničené (limitované), alebo nie.
} 
konvergencie, znovu potvrdzujúcich, že biologická evolúcia sama dokáže opakovane vyhl'adávat' tie isté „,konštrukčné“ riešenia. ${ }^{21}$

Práve preto sa čoraz viac prikláňame na stranu tých bádatel'ov, ktorí považujú všetky živé systémy za úplne autentické, svojbytné a neredukovatel'né na fyzikálne, chemické alebo sociálno-kultúrne systémy, predpokladajúc, že ríša živého je od svojho vzniku až do svojho zániku riadená svojbytnými a plnohodnotnými biologickými zákonmi, tak ako to robí najmä J. Press (2009), odmietajúci hned' v úvode svojej štúdie všetky tvrdenia o tom, že fyzikálne zákony ovel'a lepšie zodpovedajú či vyhovujú Hempelovmu modelu vysvetlenia zahrnujúcim zákonom (angl. Covering Law Thesis - Viceník, 1988, s. 89) ako biologické zákony, pretože ak aj uznáme, že zhl'adiska ich explanačných možností alebo funkcií existujú medzi fyzikou a biológiou určité rozdiely, na rovnocennej a plnohodnotnej aplikovatel'nosti Hempelovho modelu aj v rámci biológie sa tým nič podstatného nezmení. Ako d'alej upozorňuje J. Press (tamže, s. 359), tieto pochybnosti o užitočnosti či empirickej „dôveryhodnosti“ biologických explanácii pramenia najmä z neochoty niektorých bádatel'ov priznat' biologickým zákonom taký istý status ako fyzikálnym, resp., v krajnom prípade, pripustit' vôbec ich existenciu, ale tým pádom, dovolíme si doplnit', aj akceptovat' samotnú existenciu biologickej ríše ako takej.

Podl'a A. Rosenberga (tamže, s. 360-361) sa napríklad biologické explanácie vzt'ahujú k biologickým empirickým zákonom v rovnakej miere, ako sa vzt́ahujú fyzikálne explanácie kfyzikálnym empirickým zákonom, ale biologických empirických zákonov je ovel'a menej ako fyzikálnych, zatial' čo podl'a E. Sobera sú biologické zákony na rozdiel od fyzikálnych nie empirické, ale apriórne, no a P. Kitcher už odmieta pripustit' samotnú existenciu biologických zákonov ako takých. J. Press však neprijíma Rosenbergov pokus o axiomatizáciu Darwinovho prirodzeného výberu (tamže, s. 361-363), súhlasiac pritom s Kitcherom, že Rosenbergom vyčlenené biologické „zákony“ nemajú žiadnu explanačnú silu, pretože (tamže, s. 362) každý začínajúci študent biológie vraj vie, že jednotliví príslušníci druhu sa od seba líšia, že tieto odlišnosti môžu viest' $\mathrm{k}$ ich rozdielnej zdatnosti a že mlád'atá sa zvyčajne podobajú na svojich rodičov. Neakceptuje ani (tamže, s. 363-364) Soberovo stotožňovanie biologických zákonov s matematickými modelmi či zákonmi a priori, ako je napríklad Hardyho-Weinbergov zákon ${ }^{22}$, pretože ten má vo vzt'ahu k biologickej evolúcii ako takej zhruba rovnakú explanačnú silu ako tvrdenie, že dve jablká v jednej ruke a tri pomaranče v druhej dávajú spolu pät' kusov ovocia.

\footnotetext{
${ }^{21}$ A to aj vtedy a „tam“, kde by sme to vôbec nečakali, ako nedávno zistila L. Marinová (2000), poukazujúc na vel'mi rýchly rast vel'kosti mozgu v pomere $\mathrm{k}$ telu nielen u l'udí, ale aj u niektorých druhov delfínov či vel'rýb.

${ }^{22}$ Podl'a ktorého (Flegr, 2005, s. 127; podč. J. F.) sú frekvencie jednotlivých genotypov ,jednoznačne určené frekvenciou jednotlivých alel v danom genofonde“, pričom ,pre gén vyskytujúci sa iba v dvoch alelách $\mathbf{A}$, a s frekvenciami $p, q$ možno frekvencie troch možných genotypov" vypočítat' podl'a $f_{\mathrm{AA}}=p^{2}, f_{\mathrm{Aa}}=2 p q$ a $f_{\mathrm{aa}}=q^{2}$.
} 
Rovnako dôsledne odmieta aj Kitcherov pokus z roku 1985 o realizovanie biologickej explanácie na základe tzv. darvinovských histórií bez vzt'ahu k nejakému všeobecnému alebo nadradenému biologickému zákonu, kedy sa výskyt určitej vlastnosti v rámci populácie tých či oných organizmov vysvetl'uje na základe jej výhodnosti a frekvencie vo vhodne zvolených časových úsekoch $t_{1}$ a $t_{2}$, pretože existencia určitých opakujúcich sa „vzorov“ vo výskyte tých či oných vlastností ešte nestačí na to (tamže, s. 365), aby sme pri darvinovských históriách mohli hovorit' o explanácii, ked'že tá je neodlučitel'ná od predikcie a tá je zas neodlučitel'ná od empirického vedeckého zákona, spájajúceho navzájom vysvetl'ujúce a vysvetlované. Podl'a Pressa (tamže, s. 368) má pritom Sober čiastočne pravdu v tom, že biologické explanácie sú viac závislé na apriórnych zákonoch ako fyzikálne, čo ale nič nemení na tom (tamže, s. 369), ako sme už uviedli, že táto väčšia dôležitost' apriórnych matematických modelov v biológii v nej nevylučuje aplikovanie modelu vysvetlenia zahrnujúcim zákonom, pretože pravdivost' fyzikálnych explanácii závisí takisto ako pravdivost' biologických explanácií od apriórnych zovšeobecnení, aj ked' tie ani v jednej, ani v druhej vede neplnia úlohu empirických zákonov.

V tejto zdanlivo neriešitel'nej epistemickej situácii však Press nachádza východisko (tamže, s. 370-374), a to v koncepte či pojme "dispozícií" (angl. dispositions), ako reálnych tendencií alebo „predpokladov“ materiálnych objektov správat' sa určitým, predvídatel'ným spôsobom, podotýkajúc, že aj ked'ide vel'mi kontroverzný a intenzívne diskutovaný koncept, predsa len nám dovol'uje s relatívne vel'kou istotou konštatovat' (tamže, s. 370), že tvrdenia o komplexných, viacúrovňových dispozíciách (ako je napríklad dedičnost' alebo zdatnost', na rozdiel od fundamentálnych dispozícií, ako je elektrický odpor či rozpad protónu) zahrňujú predpoklad, že tieto dispozície sa vyskytujú v dôsledku za nimi "skrytých" alebo pôsobiacich prírodných zákonitostí (angl. natural regularities), ktoré nie sú náhodné ani zázračné, a môžu tak byt' implicitne stotožnené s empirickými zákonmi. Podl'a neho ani Darwin nedisponoval teoretickou koncepciou (či kauzálnym mechanizmom), ktorý by mu umožnil vysvetlit' (tamže, s. 370-371), prečo majú organizmy evidentnú tendenciu produkovat' im podobné potomstvo, ale uspokojil sa s predstavou, že za týmto faktom musí byt́ nejaký zákonitý prírodný proces, čo mu úplne stačilo na to, aby pomocou prirodzeného výberu vysvetlil celý evolučný proces.

Vel’kou prednost'ou dispozičného ,jazyka“ tak podl'a neho je (tamže, s. 371), že nám umožňuje odvolávat' sa na tieto zákony bez toho, aby sme ich bližšie špecifikovali či dokonca presne vedeli, ktoré a aké zákony to vôbec sú. Nakoniec, ako d'alej tvrdí J. Press (tamže), aj podl'a samotného Hempela je z hl'adiska modelu vysvetlenia zahrnujúcim zákonom dôležité najmä to, aby mohol byt' daný fenomén vysvetlený v rámci určitých opakujúcich sa "vzorov" a následne predpovedaný, čo je požiadavka, ktorú údajne splnnajú všetky pravdivé biologické explanácie, a tak môžeme úplne zodpovedne tvrdit', že kdekol'vek (a kedykol'vek) sa objavia explanácie závislé od dispozičných tvrdení, 
budú tieto závisiet' aj od (empirických) zákonov a vyhovovat' tak modelu vysvetlenia zahrnujúcim zákonom. Nič na tom nemenia ani možné námietky prípadných kritikov, podl'a ktorých pri takomto prístupe poskytujeme len prísl'ub plnohodnotného vysvetlenia (spojeného s jasne vymedzenými a prezentovanými empirickými biologickými zákonmi), pretože (tamže, s. 372) aj samotný model vysvetlenia zahrnujúcim zákonom bol vždy chápaný len ako idealizácia, pripúštajúc tak podl'a Hempela aj „odchýlky“ od tohto ideálu, ním samým nazývané „čiastkové explanácie“" t. j. akési limitované predikcie.

Rovnako zrejmé je, že ani vo fyzike či iných údajne plne exaktných prírodných vedách nedokážeme vždy jednoznačne odvodit' kvantitatívne parametre daného fyzikálneho systému od jeho počiatočných podmienok a namiesto toho volíme cestu „užitočných aproximácií", ktoré nám pomáhajú pri tvorbe fyzikálnych explanácií založených na modeli vysvetlenia zahrnujúcim zákonom, aj ked' je evidentné, že nie sú s ním v úplnom súlade, resp., že mu za takýchto okolností zodpovedajú len čiastočne a aproximatívne. Ešte zložitejšia epistemická situácia je pochopitel'ne v biológii, kde sa bádatelia snažia pochopit’ fungovanie extrémne komplexných systémov, a tak sú nútení v ešte väčšej miere využívat' rôzne druhy aproximácií, resp. čiastkových explanácií, pretože inak a bez nich by neraz nedokázali vysvetlit' nič, čo ale opät' nič nemení na tom (tamže, s. 373-374), že biologické explanácie ako také, rovnako ako explanácie $\mathrm{v}$ iných prírodných a sociálnych vedách, spadajú pod Hempelov model vysvetlenia zahrnujúcim zákonom, a samotná biológia, resp. evolučná biológia je takou istou svojbytnou a plnohodnotnou vedou ako všetky ostatné prírodné a sociálne vedy, disponujúce tak vlastným predmetom skúmania, ako aj vlastným súborom pre ne špecifických zákonov alebo princípov.

Po tomto priebežnom zdôvodnení a obhájení idey progresu v biologickej evolúcii, jej principiálnej opakovatel'nosti a zákonitosti už musí nasledovat' len zdôvodnenie a obhájenie jej strednej usmernenosti, ktoré však predpokladá jednoznačné ohraničenie (či vymedzenie) biologického ako takého, či už "zdola“ (od anorganického, resp. neživého), alebo „zhora“ (od sociálno-kultúrneho), a jeho následné začlenenie do globálneho evolučného "prúdu“, pretože len tak je možné definitívne "očistit" biologické a globálno-evolučné myslenie od všetkých biocentrických alebo „panbiologických“ prímesí či „nečistôt“. V prvom prípade tak môžeme v rozpore s pesimistickými tvrdeniami A. Markoša (2003, s. 217-223) o nemožnosti presne vymedzit' či už organizmus, alebo život ako taký ${ }^{23}$ celkom konštruktívne začat' priebežnou definíciou bunky ako základného stavebného a štruktúrneho proku biologickej formy pohybu hmoty v rámci dnes dominujúcej systémovej biológie, podl'a ktorej (Dehmelt-Bastiaens, 2011, s. 219) je živá bunka dynamický, adaptabilný systém

\footnotetext{
${ }^{23}$ Ked’že žiadna z definícií života (tamže, s. 220; podč. R. B.) napríklad „nie je schopná vystihnút' rozdiel medzi životom a ne-životom, medzi životom a mechanizmami, medzi životom a ,inteligentnými' strojmi, zložitými systémami s vlastnou evolúciou, a ani medzi Gaiou - termodynamickým strojom a Gaiou - živou bytostou.“
} 
operujúci d’aleko od termodynamickej rovnováhy, ktorý z organizačného hl'adiska predstavuje súhru dvoch navzájom odlišných organizačných princípov biochemických replikačných mechanizmov a samoorganizácie. ${ }^{24}$

A následne opät' len priebežne, ale aj zdôvodnene odlíšit' živé nie od abstraktného či bližšie neurčeného neživého, mechanického a strojového, tak ako to robí A. Markoš, ale od a v rámci geologického, t. j. v rámci tých konkrétnych planetárnych podmienok, v ktorých najpravdepodobnejšie došlo kvzniku živého alebo jeho odčleneniu od geologického, tak ako to v podstate robí nielen J. Corliss (1988, s. 195-200), zdôrazňujúci spolu s H. Yockeym (tamže, s. 198), že biologicky zmysluplné sekvencie aminokyselín a nukleotidov, existujúce d'aleko od termodynamickej rovnováhy, nemôžu byt' výsledkom náhodných procesov, a tak mohli najpravdepodobnejšie vzniknút' len v termodynamicky silne nerovnovážnom prostredí, t. j. v blízkosti oceánskych hydrotermálnych prieduchov, kde vd’aka silnému konvektívnemu prúdeniu horúcej vody a existencii katalytických ílových povrchov rýchlo vznikli optimálne podmienky pre udržatel'nú organickú syntézu, ale aj G. Wächtershäuser (1992), počítajúci so vznikom života vo forme chemo-autotrofných organizmov, využívajúcich ako energetický zdroj oxidačné formovanie sa pyritu zo sírovodíka a iónov železa, či Ch. de Duve (1992), predpokladajúci takisto nenáhodný vznik života (a RNK) v rámci tzv. thioesterového sveta. ${ }^{25}$

S tou doplňujúcou a upresňujúcou poznámkou, že ak spolu s J. Collierom (2008, s. 770) a nakoniec aj s J. Maynardom Smithom a Z. Szatmáryovou (tamže) uznáme, že základným predpokladom nezávislej existencie živého je oddelenie metabolizmu od replikácie v prvej autonómne fungujúcej bunke, potom prestanú byt' relevantné večné diskusie (prekvitajúce najmä v poklesnutej populárno-náučnej literatúre) o tom, či je vírus živý alebo nie, či sú živé spóry alebo nie a pod., pretože vtedy už budeme môct' bez váhania súhlasit' tak s P. Forterrom (1992), predpokladajúcim, že vírusy sa vyvinuli v rámci regresívnej evolúcie z vyhynuvšej bunečnej línie existujúcej ešte pred posledným spoločným predkom všetkých dnešných organizmov (angl. last common ancestor), ktorým zrejme nebol prokaryotický hypertermofil, ale mezofil ovel'a komplexnejší ako dnešné prokaryoty, ako aj s M. Bedauom (2008, s. 465), upozorňujúcim, že je to práve metabolizmus (sprevádzaný replikáciou pomocou genetického kódu), ktorý, tak ako tvrdil už F. Engels, umožňuje odlíšit' skutočne živé

\footnotetext{
${ }^{24} \mathrm{~V}$ origináli doslovne a presne: „Cells are dynamic, adaptable systems that operate far from thermodynamic equilibrium. Their function and structure is derived from complex biological mechanisms, which are based on several distinct organizational principles. On the one hand, master regulators, preformed templates or recipes can guide cellular structure and function. On the other hand, local interactions between fluctuating agents and growing work-in-progres can lead to de novo emergence of structures via self-organization... Upon external stimulation, many cell systems are capable of differentiating into specialized cell types to alter their behavior, function, or purpose. Such inherent plasticity of structure and function is characteristic of living organisms."

${ }^{25}$ Predstavujúceho (tamže, s. 2) akýsi most medzi abiotickým a RNK svetom, v rámci ktorého sú thioesterové chemické väzby prvými vysoko energetickými chemickými väzbami a cyklická redukcia železa (angl. iron redox cycle), podporovaná ultrafialovým žiarením, primárnym a dostatočne výdatným energetickým zdrojom.
} 
systémy od neživých kryštálov (metabolizujúcich len na svojom povrchu) a následne aj od aktuálne neživých, ale potenciálne živých systémov (čiže spór), ktoré môžu znova ožit' vo vhodných podmienkach.

$\mathrm{V}$ druhom prípade zas $\mathrm{v}$ rozpore $\mathrm{s}$ dnes čoraz populárnejšími predstavami biocentristov a rôznorodých "panbiológov" o principiálnej totožnosti evolučnokognitívnych a adaptačných procesov $\mathrm{v}$ živej prírode a v l'udskej spoločnosti konštatovat' spolu s F. Ayalom (2010), že medzi živým a sociálno-kultúrnym svetom leží principiálna a (pre všetky organizmy) doslova neprekročitel'ná hranica, pretože, ako pre zmenu tvrdil už Ch. Darwin (tamže, s. 319), iba l'udia disponujú takými rozvinutými rozumovými či intelektuálnymi schopnostami, ktoré im umožňujú dostatočne precízne anticipovat' a morálne hodnotit' ich správanie. Naše (morálne) správanie teda nie je určené biologicky, ale sociálno-kultúrne, ako tomu nasvedčuje aj tá skutočnost', že morálne kódy a/lebo normy sa menia od jednej kultúry či society k druhej, čo definitívne potvrdzuje, že tieto kódy a normy sú biologickými predispozíciami (tamže, s. 320) len podmienené, ale nie determinované (či určené). Z hl'adiska našej témy pritom vôbec nie je dôležité, či k tejto kvalitatívnej zmene, t. j. k vzniku plnohodnotnej l'udskej sociálno-kultúrnej bytosti ${ }^{26}$, došlo pred 200000 či 75000 rokmi, ale skôr to, že tieto naše výnimočné rozumové schopnosti vznikali postupne $^{27}$ a že sociálno-kultúrne sa principiálne odlišuje od biologického.

A nakoniec, v pomyselnom tret'om a záverečnom "kroku“, definitívne začlenit” všetko biologické do (hypotetického) globálneho evolučného „prúdu“, o existencii ktorého väčšina súčasných evolučných biológov nielenže pochybuje, ale vôbec odmieta hovorit', a to do určitej miery oprávnene, ako tomu nasvedčujú viaceré len čiastočne úspešné pokusy o jeho presné vymedzenie či opísanie, vrátane pokusov Stewartových (2000), Faithových (2000), Skalského (1991) alebo Poršnevových (1979). J. Stewart vo svojej inak vynikajúcej knihe ${ }^{28}$ napríklad redukuje celý obsah globálno-evolučného procesu (tamže, s. 7) len na na vzrast kooperácie medzi jednotlivými organizmami, ktorým

\footnotetext{
${ }^{26}$ Označovanej Ayalom, podl'a nás celkom správne, aj ako Homo moralis alebo Homo rationalis (tamže, s. 322).

${ }^{27}$ Podl'a F. Ayalu (tamže, s. 323) dokonca presne tak ako predpokladal F. Engels a po ňom nasledujúci, prevažne marxisticki antropológovia, t. j. počas pracovnej činnosti spojenej s výrobou čoraz komplexnejších nástrojov, v rámci ktorej si vznikajúci l'udia postupne čoraz lepšie uvedomovali (a vo svojich mozgoch v rozvíjajúcich sa či „košatejúcich“ neurónovo-dendritových siet’ach aj zaznamenávali) spojenie medzi nimi plánovanými úkonmi (či „krokmi“) a ich skutočnými alebo konečnými výsledkami; dospievajúc nakoniec do štádia (tamže, s. 324-327), kedy boli pomocou plne rozvinutého jazyka schopní uvažovat' abstraktne, t. j. začleňovat' všetky veci alebo javy do tried podl'a ich určujúcich vlastností, a zároveň slobodne volit’ medzi viacerými behaviorálnymi alternatívami. ${ }^{28}$ Ponúkajúcej čitatel'ovi (tamže, s. 86-106) najmä mimoriadne dôležité rozlíšenie lineárneho, systémového a evolučného mentálneho modelovania, v rámci ktorého lineárne mentálne modelovanie presne reprodukuje relatívne jednoduché prírodné a sociálne procesy, ale zlyháva pri opise komplexnejších prírodných a sociálnych dejov, pretože je postavené na redukcionistickej kauzálnej analýze, schopnej nanajvýš rozčlenit' skúmaný objekt na jednotlivé časti a potom postupne (akoby krok za krokom) objasnit' ich kauzálnu spätost' či súvislost'; systémové mentálne modelovanie už dokáže vyčlenit' a objasnit' najdôležitejšie (čiže systémotvorné) interakcie a vzt'ahy a na ich základe potom vymedzit' hlavné organizačné princípy príslušného celostného a organického systému, ale neumožňuje jasne vyčlenit' dlhodobé behaviorálne priority či už na individuálnej, alebo kolektívnej úrovni, a tak ho musí doplnit' evolučné mentálne modelovanie, ktoré sa zameriava na určenie hlavných trendov vo vývoji komplexných prírodných a sociálnych systémov a s nimi súvisiacich behaviorálnych stratégii a priorít.
} 
sa počas evolúcie (údajne) darí čoraz viac a lepšie prispôsobovat' individuálne záujmy záujmom kolektívnym, predpokladajúc dokonca, že práve takéto kooperujúce organizmy alebo sociálne jednotky nakoniec ovládnu nielen Zem, ale aj celý vesmír, a vôbec si neuvedomujúc, že vývojové procesy sa plnohodnotne realizujú aj na úrovni neživého a že po biologickej a sociálnej forme pohybu hmoty môže nasledovat' nielen nadsociálna forma jej pohybu, ako sme už upozorňovali, ale aj také vy̌šsie formy jej pohybu, ktoré si s našimi súčasnými konceptuálnymi prostriedkami zatial' nedokážeme ani predstavit'.

J. Faith vo svojej vel'mi nekonvenčnej doktorandskej práci (2000) takisto odôvodnene vystupuje proti redukcionistickej metafyzike, predpokladajúcej, že objekty de facto existujú v silnej izolovanosti od svojho prostredia a ich vlastnosti sú im tak vlastné alebo „intrinzické“, ponúkajúc namiesto nej antiredukcionistickú (dialekticko-materialistickú) filozofiu, v rámci ktorej sú objekty nielen prirodzene "zasadené“ do svojho prostredia a toto prostredie fakticky (spolu)určuje ich vlastnosti, ale vel'ký dôraz sa kladie (tamže, s. 11-24) aj na vymedzenie toho, ako fungujú systémy vo svojom vnútri a v interakcii so svojím bezprostredným okolím, ibaže opät' len na úrovni biologického a sociálno-kultúrneho; zatial' čo B. Poršnev (1979) už nielen hovorí o akcelerácii vývojových procesov v rámci celého zemského ekosystému, ale v rámci biologickej evolúcie poukazuje aj, ako sme už takisto upozorňovali, na vzrastajúcu nezávislost' (a autonómnost') organizmov od ich čoraz širšieho životného prostredia, práve na základe čoraz efektívnejšie využívaného mechanizmu útlmu bezprostredných reakcií (tamže, s. 287-288) a s tým spojeného čoraz diferencovanešieho, variabilnejšieho a "zacielenejšieho" správania, ale takisto nedokáže začlenit’ biologickú evolúciu do širšieho evolučného „rámca“.

A hoci sa M. Skalský (1991, s. 80-81) ako jediný z nami doteraz uvedených autorov už približuje celistvému uchopeniu globálneho evolučného „prúdu“, spájajúc vývin s rastom miery sebaurčovania akéhokol'vek organického systému, t. j. s tým, či vôbec a do akej miery daný systém "sám determinuje svoju existenciu“ (resp. sebazapríčiňuje a sebapodmieňuje sa), predsa len nedokáže postrehnút', že pri ním postulovanej relativizácii rozdielu medzi celkom, častami a okolím musíme síce predpokladat' na konci celého takéhoto vývinovo-integračného radu totalitu (tamže, s. 81), „v ktorej sa úplne potláča rozdiel medzi ňou samou, jej čast'ami a okolím“, ale tou podl'a nášho názoru nemôže byt' vesmír ako celok, "pozostávajúci", ako predpokladá jeho brat V. Skalský (1996, s. 574), z nekonečného „radu“ konkrétnesubstančne relatívne odlišných, hmoto-priestoro-časovo oddelených (a teda nezapríčinených) vesmírov, pretože, ako nakoniec pripúšt́a aj sám M. Skalský (1991, s. 81), pri takomto „supersystéme“, ktorý jeho brat Vladimír stotožňuje s vákuom ako jedinou skutočne fundamentálnou alebo „neohraničenou“ fyzikálnou substanciou (Skalský-Šipov, 1992), naozaj nemá zmysel hovorit’ o jeho sústavnom, ale len sprostredkovanom $a$ "pretržitom" zdokonal'ovaní sa alebo vývine. 
To bol aj hlavný dôvod, pre ktorý sme sa vo viacerých našich štúdiách (Burgan, 2010a, 2011, 2012) rozhodli na základe Černíkovho (1986, s. 432-433) precízneho vymedzenia jednoduchej, zúženej a rozšírenej reprodukcie organických systémov prísne rozlišovat' medzi multivesmírnym vývojom v pravom slova zmysle (pri ktorom sa z vákua vyčleňujú jednotlivé hmoto-priestoro-časovo oddelené vesmíry), vývojom vesmíru (ako vývojom jediného nami bezprostredne pozorovaného fyzikálneho objektu, s dopredu zadaným začiatkom i koncom, s vlastným, dlhodobo sa uchovávajúcim fyzikálnym obsahom a tak aj s vlastnými stavebnými, štruktúrnymi alebo substanciálnymi prvkami) a nakoniec na tomto mieste pre nás očividne najdôležitejším vývojom vo vesmíre (zastúpeným Zubkovom (1981, s. 134-153) vymedzeným vývinovým radom jednotlivých hlavných foriem pohybu hmoty), ktorý nám konečne dovol'uje vidiet' živé nielen v celej jeho historickej a časopriestorovej ohraničenenosti, pretože len na Zemi sa zatial' vyskytujúci (či dokázaný) život nachádzame takmer na konci tohto vývinového radu ${ }^{29}$, ale aj v jeho kvalitatínej špecifickosti, t. j. v jeho odlišnosti tak od všetkých slabo usmerňovaných neživých systémov, ako aj všetkých silne usmerňovaných sociálnych systémov.

Len z takejto globálno-evolučnej perspektívy potom môžeme vidiet' živé aj v celej jeho extrémne vysokej pravdepodobnosti, t. j. ako výsledok kontinuálneho a sústavného rastu usporiadanosti $\mathrm{v}$ rámci av následnosti jednotlivých vývinových stupňov vesmírnej matérie (alebo hlavných foriem pohybu hmoty), ako špecifickú a zároveň všeobecnú (alebo typickú) kvalitu, ktorá s vysokou pravdepodobnost'ou vzniká len v určitej fáze fyzikálno-chemického vývoja špirálových galaxií, v špecifických podmienkach tzv. korotačného pásma (Maročnik-Muchin, 1986, s. 154-155), kde sa v určitom "historickom" čase utvárajú podmienky vhodné pre vznik dlhodobo obývatel'ných planetárnych sústav, ktoré sa nielen počas svojej existencie pohybujú v relatívne bezpečnom korotačnom pásme (mimo sfér, kde explodujú supernovy a pod.), ale disponujú aj parametrami (Ward-Brownlee, 2003a), ako je napríklad dlhodobá existencia takmer kruhových obežných dráh všetkých planét, zvláštna poloha Jupitera pred terestrickými planétami, ktorá z neho robí vel'mi efektívneho "čističa" kometárneho „smetia“, či platňová tektonika na niektorých planétach, generujúca najdôležitejšie biochemické cykly a pod., bez ktorých by zrejme bolo márne dúfat' v dlhodobý vývin pozemského typu života.

A najmä, ako sme už viackrát konštatovali, v celej jeho systémovej špecifickosti, resp. strednej usmernenosti, ktorá nie je daná len väčším počtom zákonov a väčšou autonómnost'ou štruktúrnych prvkov biologickej formy pohybu hmoty v porovnaní s predošlými pohybovými formami, či nižším počtom $\mathrm{v}$ jej rámci pôsobiacich

${ }^{29}$ Pozostávajúceho z fyzikálnej, atómovej, chemickej, mineralogickej, petrologickej, planetárnej, hviezdnoplanetárnej, geologickej, biologickej a sociálnej (ba niekde možno aj nadsociálnej - R. B.) formy pohybu hmoty a reprezentujúceho (Burgan, 2011, s. 171) samotnú prírodu, resp. prírodu vo vlastnom slova zmysle, nami takto definovanú nie ako protiklad všetkého umelého či ako bezprostredné životné prostredie človeka vôbec, ale ako vývinový rad, k dočasnému rozvíjaniu ktorého môžeme reálne „vzt’ahovat' všetky naše nádeje, túžby a ciele“. 
zákonov a ovel'a menšou autonómiou jej štruktúrnych prvkov v porovnaní so sociálnou formou pohybu hmoty, ako sme konštatovali v našom predošlom článku (Burgan, 2012, s. 1), ale aj a predovšetkým neteleologickou (t. j. nie dopredu zadanou ani vnútornou) účelnostou (alebo účelovostou) živých systémov, ktorá prirodzene vzniká počas ich prispôsobovania sa meniacim abioticko-biotickým podmienkam (JablokovJusufov, 1985, s. 161), a ako taká principiálne odlišuje živé systémy od nežiớch, ktoré sa svojmu prostrediu neprispôsobujú, ani neakumulujú získané informácie o vonkajšom prostredí vo „vnútri“ osobitne vyčleneného informačného „zásobníka“ (alebo genofondu), ako aj od sociálnych (či sociálno-kultúrnych) a ciel'avedomých, ktoré už pomocou symbolických sústav akumulujú informácie aj bez účasti dedičných mechanizmov, a sú tak schopné pochopit” vnútornú „logiku“ nielen celovesmírneho, ale aj lokálneho biologického evolučného procesu.

\section{Záverečné poznámky}

Bez ohl'adu na to, ako bude d'alej prebiehat' nami práve otvorená diskusia o principiálnej progresívnosti, opakovatel'nosti, zákonitosti a strednej usmernenosti biologického evolučného procesu, si už teraz dovolíme poznamenat', že ak máme vo všetkom, čo sme vyššie uviedli, aspoň v najhrubších „obrysoch“ pravdu, tak d'alej už nebude vhodné hovorit' o hl'adaní inteligentného života vo vesmíre, pretože taký život jednoducho neexistuje. Viac či menej inteligentní sú teda len jednotliví l'udia ako základné stavebné, štruktúrne alebo substanciálne prvky sociálnej formy pohybu hmoty, zatial' čo jednotlivé organizmy - ako substanciálne prvky biologickej formy pohybu hmoty - jednoducho inteligentné nie sú, pretože nedisponujú jazykom a tak ani mentálnym modelovaním prírodných procesov a dejov. Rovnako pomýlené a zmätočné však boli, sú a budú aj Lovelockove pokusy stotožnit' celú Zem (či "láskyplnú“ Gaiu) s hypotetickým planetárnym superorganizmom, pretože biosféra sa nikdy nebude úplne prekrývat' s geosférou, pričom aj vzájomná interakcia či „účelová kooperácia“ týchto dvoch supersystémov je časovo limitovaná, t. j. stáva sa rozvinutou až po kambrickej explózii živého a definitívne skončí po výraznom poklese $\mathrm{CO}_{2} \mathrm{v}$ zemskej atmosfére (Ward-Brownlee, 2003b).

Pre všetky environmentálne alebo „zelené“ politické strany či hnutia, ktoré jediné majú vo svojich programoch zahrnuté dlhodobé zachovanie zemskej biosféry, to má vel'mi vážne následky a dôsledky - alebo zostanú verné dávno prekonanej biocentrickej a „panbiologickej“ evolučnej paradigme, alebo sa pokúsia zohl'adnit’ nami uvedené poznatky o dočasnej alebo historicky ohraničenej existencii všetkého živého a namiesto jednostrannej a na istý neúspech odsúdenej snahy o zachovanie biosféry a biodiverzity $\mathrm{v}$ ich súčasnom stave sa naopak pokúsia presadit' hospodárske a politické programy zamerané na kontinuálny a paralelný rozvoj tak biologickej, ako aj sociálnej formy pohybu hmoty, pretože len v jej rámci je možné vytvorit' látkovo-energeticko-informačné zdroje umožňujúce preniest' sociálnu formu pohybu 
hmoty do celej planetárnej sústavy a neskôr aj čoraz vzdialenejšieho vesmíru a predíst' tak nielen predčasnému zániku života na našej planéte a lokálnemu uzavretiu vesmírneho vývinového radu, ale aj náhlemu a čoraz pravdepodobnejšiemu pádu súčasného l'udstva do niektorého z Turčinom (2008, s. 67-69) vymedzených postapokalyptických štádií, čo je už viacero rokov naším prvoradým a čoraz odôvodnenejším životným programom a cielom (Burgan, 2000 a i.). 


\section{Bibliografie}

AMUNDSON, R. 2008. Development and Evolution. In SARKAR, S., PLUTYNSKI, A. (ed.). A Companion to the Philosophy of Biology. Oxford: Blackwell 2008. ISBN 9781-4051-2572-7, s. 248-268.

AYALA, F. J. 2010. What the Biological Sciences Can and Cannot Contribute to Ethics. In AYALA, F. J., ARP, R. (ed.). Contemporary Debates in Philosophy of Biology. Oxford: Wiley-Blackwell 2010. ISBN 978-1-4051-5998-2, s. 316-336.

BEDAU, M. A. 2008. What is Life? In SARKAR, S., PLUTYNSKI, A. (ed.). A Companion to the Philosophy of Biology. Oxford: Blackwell 2008. ISBN 978-1-40512572-7, s. 455-471.

BINKA, B. 2008. Analýza hlubinné ekologie. Brno: Masarykova univezita 2008. 199 s. ISBN 978-80-210-4548-4.

BURGAN, R. 2000. Problém vesmírnej migrácie. In Enviromagazín, roč. 5, 2000, č. 3. ISSN 1335-1877, s. 32-33.

BURGAN. R. 2010a. Vyvíja sa pozorovaný vesmír? V tlači.

BURGAN, R. 2010b. Sociálna forma pohybu hmoty (a jej hlavné, štruktúrne prvky). In E-LOGOS. Electronic Journal for Philosophy, 10/2010. ISSN 1211-0442, s. 1-20. [cit. 2012-02-28]. Dostupné na internete: <http://nb.vse.cz/kfil/elogos/science/burgan10.pdf>

BURGAN, R. 2011. Neantropocentrizmus (bohužial' a chvalabohu) určite nie je biocentrizmus. In RÁCZ, A. (ed.). (Úvahy) o biocentrizme a humanizme. Zvolen: Technická univerzita 2011. ISBN 978-80-8093-156-8, s. 166-176.

BURGAN, R. 2012. Ako a čím sa od seba odlišujú slabo, stredne a silne usmernené procesy. $\mathrm{V}$ recenznom konaní.

CARROLL, L. 1984. Alica v krajine zázrakov. Bratislava: Mladé letá 1984. 230 s.

CARROLL, S. B. 2010. Nekonečné, nesmírně obdivuhodné a překrásné. Nová věda evodevo. Praha: Academia 2010. 350 s. ISBN 978-80-200-1800-7.

COLLIER, J. 2008. Information in Biological Systems. In ADRIAANS, P., VAN BENTHEM, J. (ed.). Philosophy of Information. Amsterdam - Oxford: Elsevier 2008. ISBN 978-0-444-51726-5, s. 763-787. 
CORLISS, J. B. 1988. Hydrothermal energy flow of planetary bodies and the creation of living systems. In MARX, G. (ed.). Bioastronomy - the Next Steps. Dordrecht-Boston-London: Kluwer Academic Publishers 1988. ISBN 90-277-27147, s. 195-200.

ČERNÍK, V. 1986. Systém kategórii materialistickej dialektiky. Bratislava: Pravda 1986. $736 \mathrm{~s}$.

ČERNÍK, V., FARKAŠOVÁ, E., VICENÍK, J. 1987. Teória poznania (Úvod do dialektiky ako logiky poznania). Bratislava: Pravda 1987. 376 s.

DAVIES, P. 2001. Pátý zázrak. Pátrání po pưvodu života. Praha: Columbus 2001. 312 s. ISBN 80-7249-094-X.

DE DUVE, CH. 1992. The thioester world. In TRÂNH THANH VAN, J., TRÂNH THANH VAN, K., MOUNOLOU, J. C., SCHNEIDER, J., MCKAY, C. (ed.). Frontiers of Life. Gif-sur-Yvette Cedex: Editions Frontiers 1992. ISBN 2-86332-125-0, s. 1-20.

DEHMELT, L., BASTIAENS, P. 2011. Self-Organization in Cells. In MEYERORTMANS, H., THURNER, S. (ed.). Principles of Evolution. From the Planck Epoch to Complex Multicellular Life. Berlin-Heidelberg: Springer-Verlag 2011. e-ISBN 978-3$642-18137-5, \quad$ s. 219-238.

DEVALL, B., SESSIONS, G. 1997. Hlboká ekológia. Tulčík: Abies 1997. 336 s. ISBN 80-88699-12-6.

DUBNIČKA, J. 1989. Kategória vývoj a prírodné vedy. In Filozofia, roč. 44, 1989, č. 3. ISSN 0046-385 X, s. 270-281.

ELGIN, M. 2010. Reductionism in Biology: An Example of Biochemistry. In STADLER, F. (ed.). The Present Situation in the Philosophy of Science. DordrechtHeidelberg-London-New York: Springer 2010. e-ISBN 978-90-481-9115-4, s. 195203.

FAITH, J. 2000. Emergent Representations: Dialectical Materialism and the Philosophy of Mind. [cit. 2012-02-28]. Dostupné na internete: <http://computing.unn.ac.uk./staff/cgif1/ thesis.html>

FLEGR, J. 2005. Evoluční biologie. Praha: Academia 2005. 560 s. ISBN 80-200-1270-2. 
FORTERRE, P. 1992. New hypotheses about the origins of viruses, prokaryotes and eukarytoes. In TRÂNH THANH VAN, J., TRÂNH THANH VAN, K., MOUNOLOU, J. C.,

SCHNEIDER, J., MCKAY, C. (ed.). Frontiers of Life. Gif-sur-Yvette Cedex: Editions Frontiers 1992. ISBN 2-86332-125-0, s. 221-233.

GÁLIK, D. 1996a. Teória evolúcie z pohl'adu filozofie (I) (Vybrané kapitoly). In Organon F, roč. 3, 1996, č. 1. ISSN 1335-0668, s. 87-93.

GÁLIK, D. 1996b. Teória evolúcie z pohl'adu filozofie (II) (Vybrané kapitoly). In Organon F, roč. 3, 1996, č. 2. ISSN 1335-0668, s. 191-198.

GÁLIK, D. 1996c. Teória evolúcie z pohl'adu filozofie (III) (Vybrané kapitoly). In Organon F, roč. 3, 1996, č. 2. ISSN 1335-0668, s. 312-319.

GÁLIK, D. 1996d. Teória evolúcie z pohl'adu filozofie (IV) (Vybrané kapitoly). In Organon F, roč. 3, 1996, č. 4. ISSN 1335-0668, s. 413-420.

GÁLIK, D. 1997a. Teória evolúcie z pohl'adu filozofie (V) (Vybrané kapitoly). In Organon F, roč. 4, 1997, č. 1. ISSN 1335-0668, s. 78-86.

GÁLIK, D. 1997b. Teória evolúcie z pohl'adu filozofie (VI) (Vybrané kapitoly). In Organon F, roč. 4, 1997, č. 2. ISSN 1335-0668, s. 189-197.

GÁLIK, D. 1997c. Teória evolúcie z pohl'adu filozofie (VII) (Vybrané kapitoly). In Organon F, roč. 4, 1997, č. 3. ISSN 1335-0668, s. 302-310.

GÁLIK, D. 1997d. Teória evolúcie z pohl'adu filozofie (VIII) (Vybrané kapitoly). In Organon F, roč. 4, 1997, č. 4. ISSN 1335-0668, s. 409-418.

GÁLIK, D. 2009. Darwin, evolúcia a progresívny vývoj. [cit. 2012-02-28]. Dostupné na internete: <http:/ / dai.fmph.uniba.sk/events/kuz2009/prispevky-pdf/galik.pdf>

GOULD, S. J. 1988. Pandin palec. Malá tajemstuí evoluce. Praha: Mladá fronta 1988. $352 \mathrm{~s}$.

HAVLÍK, V., Ȟ̌ÍBEK, T. et al. 2011. Z evolučnîho hlediska. Pojem evoluce v současné filosofii. Praha: Filosofia 2011. 338 s. ISBN 978-80-7007-358-2.

JABLOKOV, A. V., JUSUFOV, A. G. 1985. Evolučná teória. Bratislava: Slovenské pedagogické nakladatel'stvo 1985. 296 s. 
LOMBORG, B. 2006. Skeptický ekolog. Jaký je skutečný stav světa. Praha: DokořánLiberální institut 2006. 588 s. ISBN 80-7363-059-1 (Dokořán) a 80-86389-42-4 (Liberální institut).

LOVELOCK, J. E. 1994. Gaia. Živoucí planeta. Praha: Mladá fronta 1994. 221 s. ISBN 80-204-0436-8.

LOVELOCK., J. E. 2007. The Revenge of Gaia. Why the Earth is Fighting Back - and How We Can Still Save Humanity. London: Penguin Books 2007. 222 s. ISBN 978-0141-02597-1.

MARINO, L. 2000. Turning the Empirical Corner on $\mathrm{F}_{\mathrm{i}}$ : The Probability of Complex Intelligence. In LEMARCHAND, G. A., MEECH, K. J. (ed.). Bioastronomy '99. A new era in bioastronomy. San Francisco: Astronomical Society of the Pacific 2000. ISBN 1-58381-044-7, s. 431-435.

MARKOŠ, A. 1997. Povstáváni živého tvaru. Praha: Vesmír 1997. 311 s. ISBN 8085977- 05-2.

MARKOŠ, A. 2003. Tajemství hladiny. Hermeneutika živého. Praha: Dokořán 2003. 352 s. ISBN 80-86569-67-5.

MAROČNIK, L. S., MUCHIN, L. M. 1986. Galaktičeskij „pojas žizni“. In MOROZOVA, N. D. (ed.). Prošloje i buduščeje Vselennoj. Moskva: Nauka 1986, s. 151-160.

NEUBAUER, Z. 2002. Biomoc. Praha: Malvern 2002. 277 s. ISBN 80-902628-7-2.

NOSEK, V., HAVLÍK, V. (ed.). 2008. Evoluce a věda. Nymburk: OPS 2008. 381 s. ISBN 978-80-87269-04-6.

OKASHA, S. 2008. The Units and Levels of Selection. In SARKAR, S., PLUTYNSKI, A. (ed.). A Companion to the Philosophy of Biology. Oxford: Blackwell 2008. ISBN 978-1-4051-2572-7, s. 138-156.

POPPER, K. R. 1994a. Bída historicismu. Praha: Oikoymenh 1994. 132 s. ISBN 8085241-75-1.

POPPER, K. R. 1994b. Otevřená společnost a její nepřátelé I. a II. Praha: Oikoymenh 1994. 356 a 388 s. ISBN 80-85241-53-6 a 80-85241-54-4. 
POPPER, K. R. 1997. Logika vědeckého bádání. Praha: Oikoymenh 1997. 618 s. ISBN 80-86005-45-3.

PORŠNEV, B. F. 1979. O začiatkoch l'udských dejín. Bratislava: Pravda 1979. 472 s.

PRESS, J. 2009. Physical explanations and biological explanations, empirical laws and apriori laws. In Biology \& Philosophy, 2009, Vol. 24, Issue 3, s. 359-374. ISSN 0169-3867. [cit. 2012-02-28]. Dostupné na internete: <DOI: 10.1007/s10539-0079096-4>

ROSSLENBROICH, B. 2009. The theory of increasing autonomy in evolution: a proposal for understanding macroevolutionary innovations. In Biology $\mathcal{E}$ Philosophy, 2009, Vol. 24, Issue 5, s. 623-644. ISSN 0169-3867. [cit. 2012-02-28]. Dostupné na internete: <DOI: 10.1007/s10539-009-9167-9>

SKALSKÝ, M. 1991. Je súčasná kozmológia vývinovou teóriou? In DUBNIČKA, J. (ed.). Vesmír a vývoj. Bratislava: Filozofický ústav SAV 1991, s. 78-92.

SKALSKÝ, V. 1996. Celostná diferencovane-súvislá realita a dynamika vesmírov. In Filozofia, roč. 51, 1996, č. 9. ISSN 0046-385 X, s. 569-578.

SKALSKÝ, V., ŠIPOV, G. 1992. Filozoficko-fyzikálne aspekty pôvodu fundamentálnych konštánt. In DUBNIČKA, J. (ed.). Filozofia, prírodné vedy a vývoj. Bratislava: Filozofický ústav SAV 1992, s. 98-102.

STANKO, V. 1987. K protirečeniam vo vývine živého. In Filozofia, roč. 42, 1987, č. 6. ISSN 0046-385 X, s. 727-736.

STANKO, V. 1989. Úrovne živého a dialektika. In Filozofia, roč. 44, 1989, č. 6. ISSN 0046-385 X, s. 710-723.

STEWART, J. 2000. Evolution's Arrow. The Direction of Evolution and the Future of Humanity. Canberra: The Chapman Press 2000. 176 s. ISBN 0-646-39497-5.

TURČIN, A., 2008: Structure of the Global Catastrophe. Moscow: Russian Transhumanist Movement. [cit. 2012-02-28]. Dostupné na internete: <http://www.scribd.com/doc/6250 354/STRUCTURE-OF-THE-GLOBALCATASTROPHE-Risks-of-human-extinction-in- the-XXI-century->

TURNER, D. 2009. How much can we know about the causes of evolutionary trends? In Biology \& Philosophy, 2009, Vol. 24, Issue 3, s. 341-357. ISSN 0169-3867. [cit. 2012-02-28]. Dostupné na internete: <DOI: 10.1007/s10539-008-9139-5.> 
TURNER, D. D. 2011. Gould's replay revisited. In Biology E Philosophy, 2011, Vol. 26, Issue 1, s. 65-79. ISSN 0169-3867. [cit. 2012-02-28]. Dostupné na internete: <DOI:10.1007/s 10539-010-9228-0>

VICENÍK, J. 1988. Spory o charakter metodológie vied (Problémy a tendencie). Bratislava: Pravda 1988. 456 s.

WÄCHTERSHÄUSER, G. 1992. Order out of order. Heritage of the iron-sulfur world. In TRÂNH THANH VAN, J., TRÂNH THANH VAN, K., MOUNOLOU, J. C., SCHNEIDER, J., MCKAY, C. (ed.). Frontiers of Life. Gif-sur-Yvette Cedex: Editions Frontiers 1992. ISBN 2-86332-125-0, s. 21-39.

WARD, P. D., BROWNLEE, D. 2003a. Rare Earth. Why Complex Life is Uncommon in the Universe. New York: Copernicus 2003. 335 s. ISBN 0-387-95289-6.

WARD, P. D., BROWNLEE, D. 2003b. The Life and Death of Planet Earth. How the New Science of Astrobiology Charts the Ultimate Fate of Our World. New York: Henry Holt 2003. 241 s. ISBN 0-8050-6781-7.

ZRZAVÝ, J., STORCH, D., MIHULKA, S. 2004. Jak se dělá evoluce. Od sobeckého genu k rozmanitosti života. Praha-Litomyšl: Ladislav Horáček-Paseka 2004. 296 s. ISBN 80-7185-578-2.

ZUBKOV, I. F. 1981. Problém geologickej formy pohybu hmoty. Bratislava: Pravda 1981. $272 \mathrm{~s}$. 


\section{E-LOGOS}

ELECTRONIC JOURNAL FOR PHILOSOPHY

Ročník/Year: 2012 (vychází průběžně/ published continuously)

Místo vydání/Place of edition: Praha

ISSN 1211-0442

Vydává/Publisher:

Vysoká škola ekonomická v Praze / University of Economics, Prague

nám. W. Churchilla 4

Czech Republic

13067 Praha 3

IČ: 61384399

Web: http://e-logos.vse.cz

Redakce a technické informace/Editorial staff and technical information:

Miroslav Vacura

vacuram@vse.cz

Redakční rada/Board of editors:

Ladislav Benyovszky (FHS UK Praha, Czech Republic)

Ivan Blecha (FF UP Olomouc, Czech Republic)

Martin Hemelík (VŠP Jihlava, Czech Republic)

Angelo Marocco (Pontifical Athenaeum Regina Apostolorum, Rome, Italy)

Jozef Kelemen (FPF SU Opava, Czech Republic)

Daniel Kroupa (ZU Plzeň, Czech Republic)

Vladimír Kvasnička (FIIT STU Bratislava, Slovak Republic)

Jaroslav Novotný (FHS UK Praha, Czech Republic)

Jakub Novotný (VŠP Jihlava, Czech Republic)

Ján Pavlík (editor-in-chief) (VŠE Praha, Czech Republic)

Karel Pstružina (VŠE Praha, Czech Republic)

Miroslav Vacura (executive editor) (VŠE Praha, Czech Republic) 